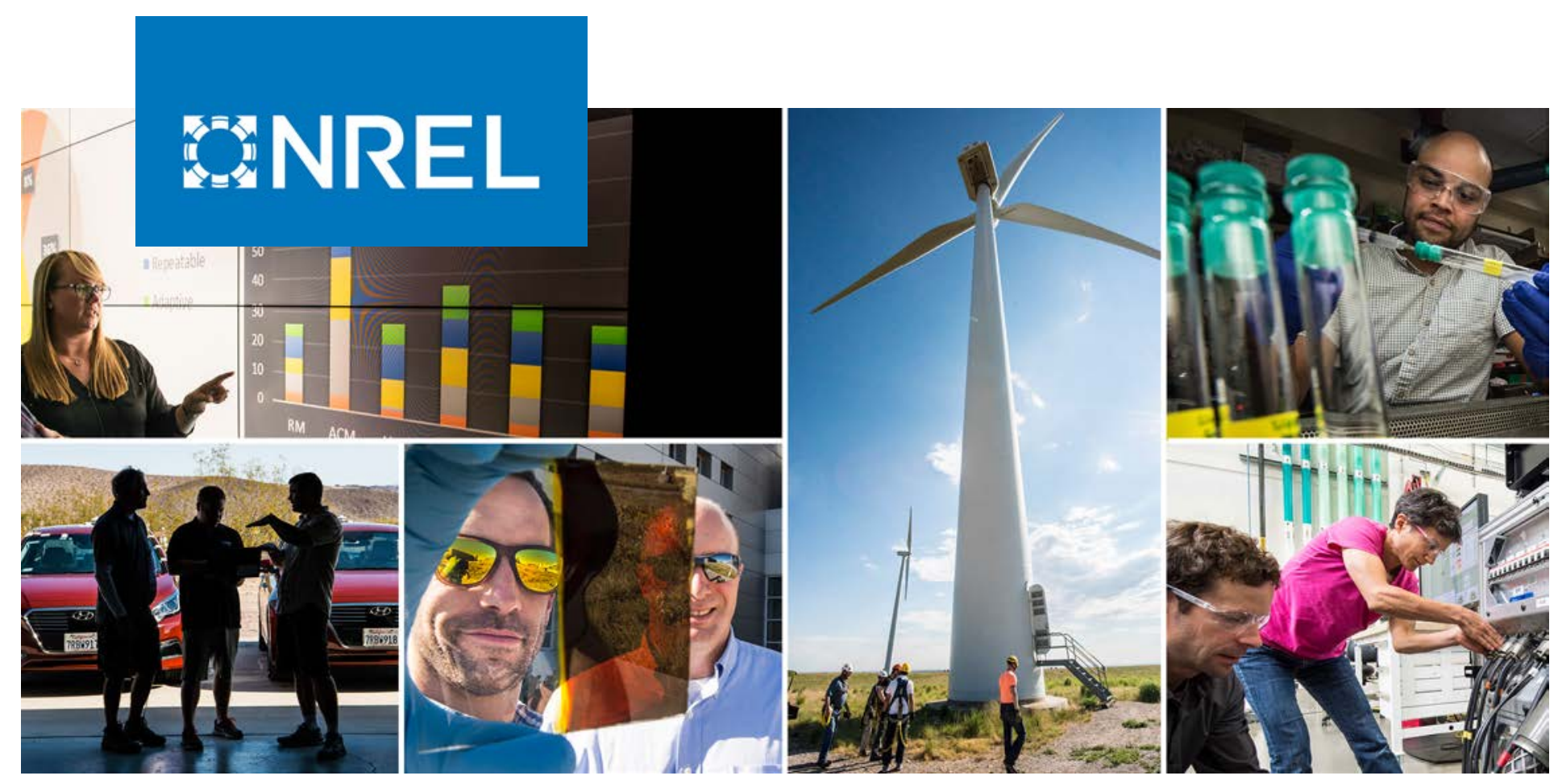

\title{
Accelerating Systems Integration Standards (ACCEL)
}

David Narang, ${ }^{1}$ Andy Hoke, ${ }^{1}$ Sigifredo Gonzalez, ${ }^{2}$

Rasel Mahmud, ${ }^{1}$ Jay Johnson, ${ }^{2}$ and

Shazreen Meor-Danial ${ }^{1}$

1 National Renewable Energy Laboratory

2 Sandia National Laboratories

NREL is a national laboratory of the U.S. Department of Energy

Office of Energy Efficiency \& Renewable Energy

Operated by the Alliance for Sustainable Energy, LLC

This report is available at no cost from the National Renewable Energy Laboratory (NREL) at www.nrel.gov/publications.
Technical Report

NREL/TP-5D00-73020

November 2019 


\section{GNREL}

\section{Accelerating Systems Integration Standards (ACCEL)}

David Narang, ${ }^{1}$ Andy Hoke, ${ }^{1}$ Sigifredo Gonzalez, ${ }^{2}$

Rasel Mahmud, ${ }^{1}$ Jay Johnson, ${ }^{2}$ and

Shazreen Meor-Danial ${ }^{1}$

1 National Renewable Energy Laboratory

2 Sandia National Laboratories

\section{Suggested Citation}

Narang, David, Andy Hoke, Sigifredo Gonzalez, Rasel Mahmud, Jay Johnson, and Shazreen Meor-Danial. 2019. Accelerating Systems Integration Standards (ACCEL).

Golden, CO: National Renewable Energy Laboratory. NREL/TP-5D00-73020.

https://www.nrel.gov/docs/fy20osti/73020.pdf.

NREL is a national laboratory of the U.S. Department of Energy Office of Energy Efficiency \& Renewable Energy Operated by the Alliance for Sustainable Energy, LLC

This report is available at no cost from the National Renewable Energy Laboratory (NREL) at www.nrel.gov/publications.

Contract No. DE-AC36-08GO28308
Technical Report

NREL/TP-5D00-73020

November 2019

National Renewable Energy Laboratory 15013 Denver West Parkway Golden, CO 80401

303-275-3000 • www.nrel.gov 


\section{NOTICE}

This work was authored in part by the National Renewable Energy Laboratory, operated by Alliance for Sustainable Energy, LLC, for the U.S. Department of Energy (DOE) under Contract No. DE-AC36-08G028308. Funding provided by U.S. Department of Energy Office of Energy Efficiency and Renewable Energy Solar Energy Technologies Office. The views expressed herein do not necessarily represent the views of the DOE or the U.S. Government.

Sandia National Laboratories is a multimission laboratory managed and operated by National Technology and Engineering Solutions of Sandia, LLC, a wholly owned subsidiary of Honeywell International Inc., for the U.S. Department of Energy's National Nuclear Security Administration under contract DE-NA0003525.

This report is available at no cost from the National Renewable Energy Laboratory (NREL) at www.nrel.gov/publications.

U.S. Department of Energy (DOE) reports produced after 1991 and a growing number of pre-1991 documents are available free via www.OSTI.gov.

Cover Photos by Dennis Schroeder: (clockwise, left to right) NREL 51934, NREL 45897, NREL 42160, NREL 45891, NREL 48097, NREL 46526

NREL prints on paper that contains recycled content. 


\section{Acknowledgments}

The authors acknowledge the dedication and efforts of the Working Group members for IEEE Std P1547 and P1547.1 and the UL Standards Technical Panel members for UL 1741 toward the completion of these standards.

The authors are also grateful to the U.S. Department of Energy Office of Energy Efficiency and Renewable Energy Solar Energy Technologies Office technical monitors Dr. Kemal Celik and Jeremiah Miller and Systems Integration Program Manager Guohui Yuan for their guidance and support. 


\section{List of Acronyms}

\section{ACCEL}

DER

EPRI

HECO

IEEE

MPPT

NREL

PV

RLC

SA

STP

VAR
Accelerating Systems Integration Standards distributed energy resource Electric Power Research Institute Hawaiian Electric Companies Institute of Electrical and Electronics Engineers maximum power point tracking National Renewable Energy Laboratory photovoltaic resistor-inductor-capacitor Supplement A Standards Technical Panel volt ampere reactive 


\section{Executive Summary}

Dramatic increases in photovoltaic (PV) adoption in many parts of the United States have led to a heightened sense of urgency to improve national standards for the interconnection of distributed energy resources (DERs). Establishing new interconnection and interoperability requirements and conformance testing procedures to take advantage of new and emerging gridinteractive technologies will help improve the safe and efficient integration of increasing amounts of PV and other DERs into the electric power system.

The scope of work undertaken by the Accelerating Systems Integration Standards (ACCEL) team was to facilitate standards development and to help expedite the process in three important standards identified under the SunShot National Laboratory Multiyear Partnership grid performance and reliability topic area. Specifically, the standards addressed were the Institute of Electrical and Electronics Engineers (IEEE) Std 1547, IEEE Std 1547.1, and UL 1741.

The overall goal was to firmly establish new requirements extending well beyond those in the preexisting, published versions of IEEE Std 1547 (2003), IEEE Std 1547.1 (2005), and UL 1741 (first published in 1999, most recently revised in 2010). To accomplish this goal, the ACCEL team provided increased leadership and direction, used state-of-the-art workflow tools, and leveraged DER testing facilities at the National Renewable Energy Laboratory (NREL) and Sandia National Laboratories (Sandia).

Throughout the project, the ACCEL team leaders led biweekly meetings, recruited additional coleads and officers, and provided guidance and direction to the working group and subgroups for both IEEE Std P1547 and IEEE Std P1547.1. The ACCEL team also contracted with wellknown and knowledgeable individuals to provide technical input and leadership to subgroups and to present and lead discussions during working group meetings. ACCEL team members also provided technical contributions directly to working groups in several areas, including voltage regulation, unintentional islanding, DERs on secondary networks, and testing and commissioning.

Sandia and NREL conducted laboratory tests at the Distributed Energy Technology Laboratory (Sandia) and Energy Systems Integration Facility (NREL) to validate and, when needed, develop test procedures. The lessons learned were fed back into the conformance test development process in working groups and were also shared with specific DER manufacturers.

Throughout this project, the ACCEL team was instrumental in the following key outcomes:

1. UL 1741 Supplement A was published in September 2016.

2. IEEE Std $1547-2018$ was published in 2018. This is a major revision to interconnection procedures representing the consensus of hundreds of individuals, and it will have significant impacts around the United States and beyond by ensuring that DERs can fully participate in the rapidly modernizing electric grid.

3. Test procedures were validated at Sandia and NREL, and lessons were incorporated into the draft IEEE Std P1547.1, expected to be published in early 2020. 


\section{Table of Contents}

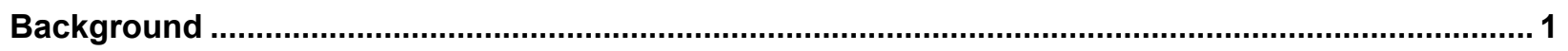

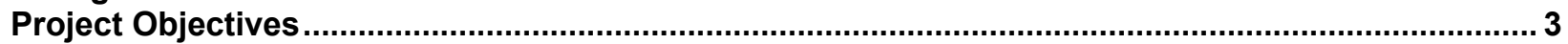

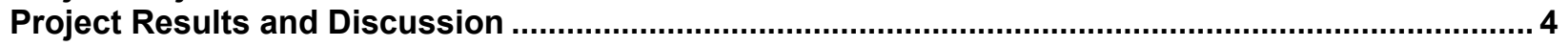

Establishment of New Grid-Support Performance Requirements.................................................. 4

Establishment of New Grid-Support Requirements in IEEE P1547 Draft................................... 4

Completion of All New Grid-Support Requirements............................................................ 7

Completion of IEEE Std P1547 Final Public Ballot ............................................................... 8

Establishment of New Grid-Support Function Conformance Testing Procedures............................... 9

Establishment of New Conformance Test Procedures for Grid-Support Functionalities in UL

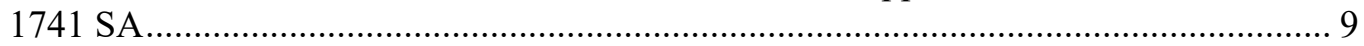

Establishment of New Conformance Test Procedures for Grid-Support Functionalities in IEEE

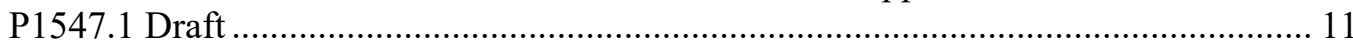

Establishment of New Test Requirements for Interoperability and Special Interconnections in

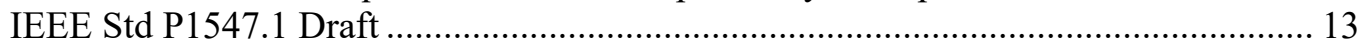

Preparation for IEEE Std P1547.1 Public Ballot.................................................................... 14

Laboratory Validation of Requirements and Conformance Testing Procedures ................................ 16

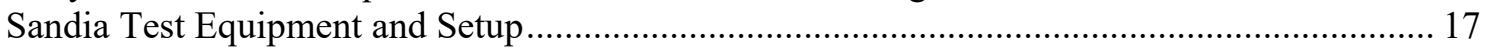

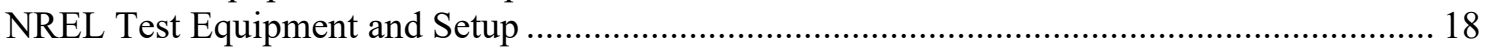

Confirmation of New Testing Procedures for PV Inverter Testing of Grid-Support Functionalities in IEEE Std P1547.1 (Addressed per Autonomous Response) ............. 20

Confirmation of Testing Procedures for Unintentional Islanding Scheme(s) with Full Suite of Grid-Support Functions Enabled (IEEE Std 1547a Settings)...................................... 23

Confirmation of New Testing Procedures for PV Inverter Conformance to Interoperability Requirements (Test via Communications) ................................................................. 23

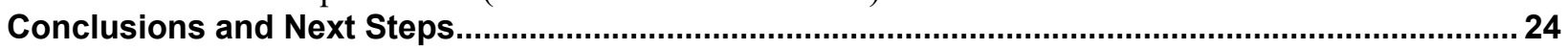

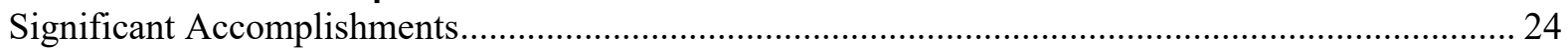

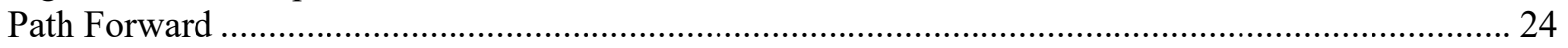

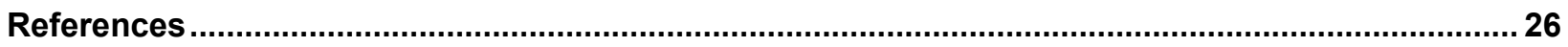

Bibliography: Inventions, Patents, Publications, and Other Results .............................................. 27

Appendix A: Issues Encountered and Lessons Learned from Laboratory Validation of Test

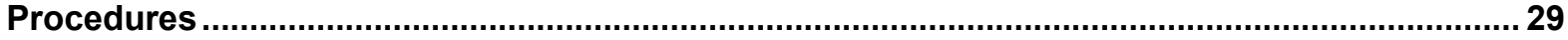




\section{List of Figures}

Figure 1. Final P1547 ballot recirculation results (R4, December 29, 2017) ....................................... 9

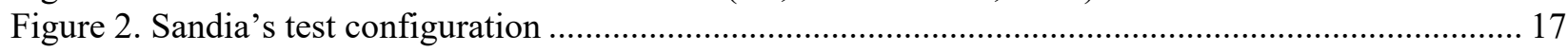

Figure 3. Lab equipment at Sandia for evaluating conformance test procedures: TerraSAS100-kW PV simulator (left); Ametek 180-kVA AC simulator (right). Photos courtesy of Sandia National

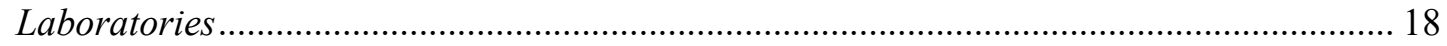

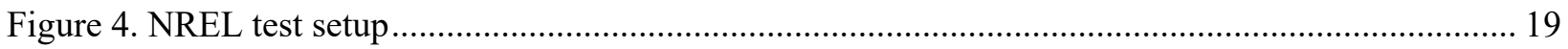

Figure 5. Inverter/transformer set: (a) 550-kVA inverter, (b) 550-kVA transformer, (c) two Magna-Power DC power supplies, (d) section of the Ametek grid simulators/power supplies. Photos

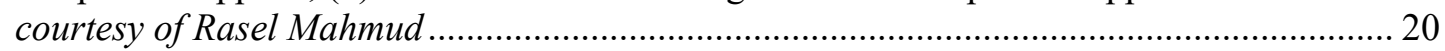

\section{List of Tables}

Table 1. ACCEL Team Members in P1547 Subgroups ...................................................................... 5

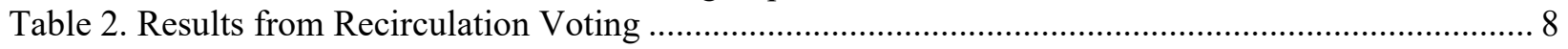

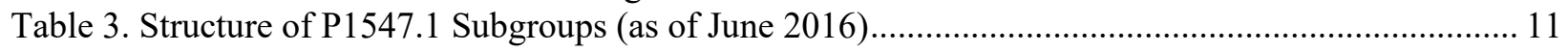

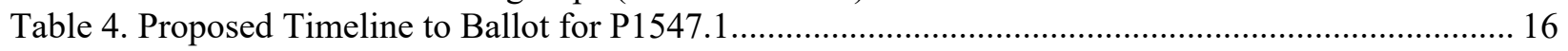

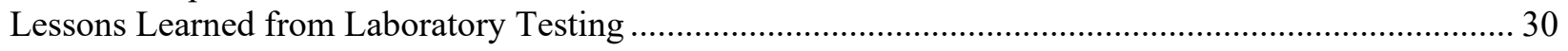




\section{Background}

The Institute of Electrical and Electronics Engineers (IEEE) Standard for Interconnecting Distributed Resources with Electric Power Systems, commonly referred to as IEEE Std 1547, was first published in 2003 (IEEE 2003). This standard was developed to provide much-needed uniform guidance for interconnecting any type of distributed energy resource (DER) to electric power systems in the United States (and could also be adopted internationally). The standard is relevant to all DER technologies, including synchronous machines, induction machines, and power inverters/converters.

IEEE Std 1547 focuses on the technical specifications of the interconnection and provides requirements to ensure and test the proper operation, performance, safety, and maintenance of the interconnection.

The original standard, only 15 pages long, had two main sections: Clause 4 issued requirements on the technical specifications and the interconnection, and Clause 5 issued requirements on interconnection test specifications and requirements.

When IEEE Std 1547 was first published in 2003, a total of 20 U.S. companies reported shipments of photovoltaic (PV) cells and modules, totaling slightly more than $109 \mathrm{MW}$. PV module cost was $\$ 3.17$ per watt. Grid-interactive electric generation accounted for less than half (42.5 MW) of the total PV shipped (U.S. Energy Information Administration 2005), with the remainder being used for non-grid-tied applications.

PV capacity increased sharply during the next decade, and by 2010 there were 112 companies in the United States manufacturing PV cells and modules, and the total amount shipped was more than $2.6 \mathrm{GW}$. Module cost had dropped to $\$ 1.86$ per watt. Grid-connected PV had increased to $1.6 \mathrm{GW}$ and was mostly distributed generation $(1.4 \mathrm{GW})$ (U.S. Energy Information Administration 2012).

Resulting in large part from the proliferation of DERs in many parts of the United States as well as from observations of distributed PV experiences in other parts of the world, an amendment to IEEE Std 1547 was issued in 2014 that allowed active voltage regulation and more flexible voltage and frequency trip settings to address emerging issues with higher levels of DERs (IEEE 2014). These capabilities were seen as necessary to allow DERs to actively participate in and support the electric grid under steady-state and abnormal voltage or frequency conditions.

Between 2003 and 2015, additional guidance on interconnection and interoperability-related topics was published in the following documents:

- 2005: IEEE Std 1547.1 - IEEE Standard Conformance Test Procedures for Equipment Interconnecting Distributed Resources with Electric Power Systems

- 2007: IEEE Std 1547.3 - IEEE Guide for Monitoring, Information Exchange, and Control of Distributed Resources Interconnected with Electric Power Systems

- 2008: IEEE Std 1547.2 - IEEE Application Guide for IEEE Std 1547, IEEE Standard for Interconnecting Distributed Resources with Electric Power Systems 
- 2011: IEEE Std 1547.4 - IEEE Guide for Design, Operation, and Integration of Distributed Resource Island Systems with Electric Power Systems

- 2011: IEEE Std 1547.6 - IEEE Recommended Practice for Interconnecting Distributed Resources with Electric Power Systems Distribution Secondary Networks

- 2011: IEEE Std 2030 - IEEE Guide for Smart Grid Interoperability of Energy Technology and Information Technology Operation with the Electric Power System (EPS), End-Use Applications, and Loads

- 2013: IEEE Std 1547.7 - IEEE Guide for Conducting Distribution Impact Studies for Distributed Resource Interconnection.

New grid-interactive devices are now being introduced and implemented at a rapid pace, and the dramatic increases in PV adoption in many parts of the United States have led to a heightened sense of urgency to the national standards development process. The scope of work undertaken by the Accelerating Systems Integration Standards (ACCEL) team was developed to address the urgency by providing leadership and direction in the three main interconnection standards under revision: IEEE Std 1547, IEEE Std 1547.1, and UL1741.

The intended result of this project was to fill current gaps in the standards to overcome barriers for PV and DER system interconnection and interoperability, which in turn will lead to more technically sound PV installations that can be used in new ways to enhance the reliability, resilience, and safety of the electric grid. 


\section{Project Objectives}

The objective of the ACCEL project was to expedite the development of interconnection standards to enable the use of modern grid-interactive devices that can be used to solve challenges related to the increased adoption of DERs in the electric distribution system. Using these new grid-interactive devices and their electric power system support capabilities and interoperability-controlled implementation, new ways to strengthen utility reliability, resilience, and the safety/protection of the electric grid can be achieved.

To achieve this objective, the project team was organized to provide leadership and direct technical contributions to the development and validation of performance requirements and conformance testing procedures in the relevant standards, as applicable: IEEE Std 1547, IEEE Std 1547a, IEEE Std 1547.1 and UL 1741 Supplement A (SA). Under these tasks, the following milestones were determined:

- Establishment of new grid-support performance requirements

- Establishment of new grid-support requirements in IEEE P1547 ${ }^{1} \mathrm{draft}$

○ Completion of all new grid-support requirements

○ Completion of IEEE P1547 final ballot.

- Establishment of new grid-support function conformance testing procedures

- Establishment of new conformance test procedures for grid-support functionalities in UL 1741 SA

- Establishment of new conformance test procedures for grid-support functionalities in IEEE P1547.1 draft.

- Establishment of new test requirements for interoperability and special interconnections in IEEE Std P1547.1 draft.

○ Completion of IEEE Std P1547.1 final public ballot.

- Laboratory validation of requirements and conformance testing procedures

- Confirmation of new testing procedures for PV inverter testing of grid-support functionalities in IEEE Std P1547.1 (addressed per autonomous response)

- Confirmation of testing procedures for unintentional islanding scheme(s) with full suite of grid-support functions enabled (IEEE Std 1547a settings) Confirmation of new testing procedures for PV inverter conformance to interoperability requirements (test via communications).

Discussion of the project results follows.

\footnotetext{
${ }^{1}$ Per IEEE Standards Association conventions, a standard preceded by a " $\mathrm{P}$ " indicates a proposed standard that has not yet been approved and published, so "P1547" refers to the draft revised standard.
} 


\section{Project Results and Discussion}

The project's period of performance was from October 2015 to September $2018 .^{2}$ The discussions are organized by task, so not all work appears chronologically.

\section{Establishment of New Grid-Support Performance Requirements}

This task included milestones to support the establishment of new grid-support requirements in the P1547 draft, completion of all new grid-support requirements, and completion of the P1547 final public ballot.

\section{Establishment of New Grid-Support Requirements in IEEE P1547 Draft}

The overall goal during the first year of the project (October 2015-September 2016) was to firmly establish new requirements extending well beyond those existing for the published IEEE Std 1547-2003. Key requirements included the establishment of new functionalities and settings for voltage and frequency ride-through, voltage regulation, and interoperability.

To support this goal, the principal investigator chaired biweekly teleconferences of the P1547 officers; led the development of the agendas and chaired the full working group meetings (October and March) of P1547 and P1547.1; established the P1547.1 organizational structure and appointed the P1547.1 officers; established the working group schedules for P1547 and P1547.1 draft completion and publication; mentored and/or coached various vice chairs and subgroup chairs to promote more effective development of the standards; and provided and planned various status updates to external groups (e.g., IEEE tutorial on the P1547 series and related P2030 series as well as Federal Energy Regulatory Commission interconnection technical, policy, and legal staff). Non-ACCEL-project industry partners were successfully recruited to take on more enhanced roles for standards development. An expert consultant, under contract to Sandia National Laboratories, was a co-leader/subgroup chair to Clause 4.2, on voltage/frequency ride-through, and was an active contributor to the volt-volt ampere reactive (volt-VAR) discussion and recommended text.

An average of 97 individuals per meeting attended during the three working group sessions (October 2015, March 2016, and June 2016), and there were more than 140 formal working group members for P1547. The member affiliations included electric utilities and cooperatives, equipment manufacturers, trade associations, standards development organizations, regulatory authorities, DER system developers, and government agencies. The entities represented by the working group members are collectively involved in distributed generation projects throughout the United States and, in some cases, internationally.

Because of the amount and detail of new requirements in both P1547 and P1547.1, the larger working groups were divided into smaller teams working in parallel to focus on specific requirements. The majority of these subgroups held regular meetings lasting from 60 to 90 minutes on a weekly basis throughout the multi-year drafting period. ACCEL team membership

\footnotetext{
${ }^{2}$ In Year 1, Q3, Principal Investigator Thomas Basso retired after 33 years of service at NREL. Principal investigator duties transferred to David Narang, who also served as P1547 Working Group Chair moving forward. Chairmanship of P1547.1 was transferred from Thomas Basso to Dr. Sudipta Chakraborty. In Year 2 Q2 (July 2017), Dr. Chakraborty resigned from NREL, and chairmanship of P1547.1 was transferred to Dr. Andy Hoke.
} 
in various subgroups is shown in Table 1. Subgroup teams held conference calls every day of the week, also as shown in Table 1. ACCEL team members led several of the subgroups and actively participated in many others.

Table 1. ACCEL Team Members in P1547 Subgroups

\begin{tabular}{|c|c|c|c|}
\hline Scope & Lead Role & $\begin{array}{l}\text { Alt. Lead and } \\
\text { Facilitator Roles }\end{array}$ & Subgroup Member Role \\
\hline $\begin{array}{l}\text { P1547 officers } \\
\text { (biweekly on Tuesday, } \\
11 \text { a.m.-12 p.m.) }\end{array}$ & $\begin{array}{l}\text { Led by ACCEL PI } \\
\text { D. Narang, } \\
\text { Working Group } \\
\text { Chair (NREL) }\end{array}$ & $\begin{array}{l}\text { C. Vartanian, } \\
\text { Working Group } \\
\text { Secretary } \\
\text { (Mitsubishi) }\end{array}$ & $\begin{array}{l}\text { S. Chakraborty (formerly } \\
\text { NREL), A. Hoke (NREL) }\end{array}$ \\
\hline $\begin{array}{l}\text { Comment Review Team, } \\
\text { Ballot Review Team }\end{array}$ & Led by D. Narang & J. Boemer (EPRI) & $\begin{array}{l}\text { S. Chakraborty, A. Hoke } \\
\text { M. Coddington (NREL) }\end{array}$ \\
\hline $\begin{array}{l}\text { Overall document } \\
\text { (weekly on Monday, } \\
4-5 \text { p.m.) }\end{array}$ & D. Narang & J. Boemer & $\begin{array}{l}\text { S. Chakraborty, } \\
\text { M. Coddington, } \\
\text { S. Gonzalez (SNL) }\end{array}$ \\
\hline $\begin{array}{l}\text { Voltage regulation } \\
\text { (weekly on Friday, } \\
11 \text { a.m.-12:30 p.m.) }\end{array}$ & $\begin{array}{l}\text { B. Enayati, } \\
\text { Working Group } \\
\text { Vice Chair } \\
\text { (National Grid) }\end{array}$ & $\begin{array}{l}\text { J. Berdner, } \\
\text { Working Group } \\
\text { Vice Chair } \\
\text { (Enphase) }\end{array}$ & $\begin{array}{l}\text { S. Chakraborty, A. Hoke } \\
\text { S. Gonzalez }\end{array}$ \\
\hline $\begin{array}{l}\text { Response to abnormal grid } \\
\text { conditions } \\
\text { (weekly on Tuesday, } \\
\text { 1-3 p.m., and Thursday, } \\
\text { 12:30-2:30 p.m.) }\end{array}$ & J. Berdner & B. Enayati & $\begin{array}{l}\text { A. Hoke, S. Gonzalez, B. } \\
\text { Mather }\end{array}$ \\
\hline $\begin{array}{l}\text { Interoperability and } \\
\text { communication } \\
\text { (weekly on Tuesday, } \\
2-3 \text { p.m.) }\end{array}$ & $\begin{array}{l}\text { B. Fox, Working } \\
\text { Group Vice Chair } \\
\text { (SunSpec) }\end{array}$ & B. Seal (EPRI) & \\
\hline $\begin{array}{l}\text { Special interconnections, } \\
\text { islanding, microgrids, storage, } \\
\text { secondary networks } \\
\text { (weekly on Friday, } \\
\text { 2-3:30 p.m.) }\end{array}$ & C. Vartanian & $\begin{array}{l}\text { M. Coddington } \\
\text { (lead for } \\
\text { secondary } \\
\text { networks) }\end{array}$ & S. Gonzalez \\
\hline $\begin{array}{l}\text { Interconnection/interoperability } \\
\text { test specifications and } \\
\text { requirements, modeling and } \\
\text { simulation } \\
\text { (weekly on Monday, } \\
\text { 1-2 p.m., and Tuesday, } \\
\text { 12:30-1:30 p.m.) }\end{array}$ & $\begin{array}{l}\text { M. Siira, Working } \\
\text { Group Vice Chair } \\
\text { (Comrent) }\end{array}$ & $\begin{array}{l}\text { W. Stec } \\
\text { (Distregen) }\end{array}$ & S. Chakraborty, A. Hoke \\
\hline $\begin{array}{l}\text { Power quality, area electric } \\
\text { power system, microgrids } \\
\text { (weekly on Friday, } \\
\text { 12:30-1:30 p.m.) }\end{array}$ & B. Enayati & $\begin{array}{l}\text { M. Page } \\
\text { (Southern Co.) }\end{array}$ & A. Hoke \\
\hline
\end{tabular}


ACCEL team members provided technical contributions and direction at weekly subgroup meetings in several topic areas, including voltage regulation, unintentional islanding, DERs located on secondary networks, testing, and overall document organization.

\section{Summary of Technical Contributions to Requirements for Voltage Regulation}

In Q1, ACCEL team members (Sudipta Chakraborty, Andy Hoke, and Sigifredo Gonzalez) supported the development of new voltage regulation requirements for P1547 based on comments received at the October working group meeting. Additionally, some of the requirements for VAR control functions, such as volt-VAR and watt-VAR, were further revised based on subgroup discussions. The National Renewable Energy Laboratory's (NREL's) and Sandia's subject matter expertise in grid integration of PV and testing various PV inverters from different manufacturers was instrumental in resolving some of these comments and finalizing the requirements. Based on NREL's work with Hawaiian Electric Companies (HECO), Hoke recommended a change in the volt-watt function specification to provide a more reliable grid service. The P1547 voltage regulation subgroup accepted the change, and it was incorporated into Draft 6.

\section{Summary of Technical Contributions to Requirements for Interconnection/ Interoperability Test Specifications and Requirements}

Given the large number of new requirements in P1547, a new subgroup was formed during the last quarter of Fiscal Year 2016 to explicitly map all these requirements to testing or verification methods in P1547.1. A matrix was developed to map each requirement to one of five verification methods: type testing, production testing, design evaluation, installation evaluation, and commissioning testing. The matrix also gave direction on where DERs should meet the requirements: at the point of interconnection or at the point of common coupling. ACCEL team members (Hoke, Chakraborty) continued attending conference calls and participated in email conversations with the goal of ensuring that verification methods adequately confirm DER behavior without imposing an undue burden on smaller DER installations.

\section{Summary of Technical Contributions to Requirements for Secondary Networks}

For revisions to this clause, the subgroup leveraged IEEE Std 1547.6 - Recommended Practice for Interconnecting Distributed Resources with Electric Power Systems Distribution Secondary Networks (IEEE 2011). ACCEL team member Michael Coddington developed the language for this clause and continued to work with a team of secondary network experts. This section was well accepted by the working group and the IEEE Standards Association balloters and received few comments during balloting. The new language for networks now provides guidance for area/street/grid networks, along with spot networks, and it adds more capabilities for the both developer and utility in downtown secondary network applications.

\section{Summary of Technical Contributions to Requirements for Response to Area EPS Abnormal Conditions}

In Q1, based on work led by Hoke under the Grid Modernization Laboratory Consortium Project 1.3.29 (Hawaii regional partnership), a recommendation was made to modify the technical specification of the frequency-watt (droop) function with a goal of accommodating low-inertia grids. The proposed change was strongly debated by the subgroup and eventually incorporated into Draft 6. 
Other areas with revised language include:

- Conditions under which the DER does not need to meet ride-through requirements were addressed, i.e., when the DER is not connected to the interconnected system.

- The response during the unavailability of the primary source of energy to the DER shall not result in a failure to comply with ride-through requirements.

- The designation of where (point of common coupling or point of interconnection) the applicable voltages are determined will now include an annual average load requirement. A decision tree (informative) graphically illustrates how to determine applicable voltage locations.

- Language was introduced that provides sign convention from the DER's generation perspective because load sign conventions are typically stated currently.

- The "return to service" requirements and when they apply were revised.

In the first year, the P1547 working group established Draft 4 and reviewed it at the June 2016 meeting. The new draft included DER technical performance categories as well as voltage and frequency ride-through, voltage regulation draft text, and updated draft interoperability inputs.

\section{Completion of All New Grid-Support Requirements}

In Year 2 (October 2016 through September 2017), ACCEL team member Coddington led the P1547 subgroup on requirements for DERs in secondary distribution networks, achieving 90\% draft text completion (Subtask 2.1.1). ACCEL team member Chakraborty was appointed as P1547.1 chair, and Hoke was appointed as P1547.1 secretary.

At the October 28, 2016, meeting, P1547 Working Group Chair David Narang created a highlevel group to increase coordination among the subgroups and to streamline comment resolution. This group, the Comment Review Team, held weekly meetings to discuss and address crosscutting issues toward addressing comments received during working group draft ballots. The group comprised all vice chairs, subgroup alternate leads, and facilitators. Members of this group were instrumental in the speedy editing and delivery of a revised draft (Draft 6) by December 19, 2016. This group had primary responsibility to work toward ensuring all comments were addressed prior to the working group meeting in February.

In Q2, ACCEL team members (Narang, chair of P1547; Chakraborty, chair of P1547.1; and Hoke, secretary of P1547.1) along with other P1547 and P1547.1 officers developed logistics and an agenda for the P1547 and P1547.1 meetings held February 27-March 1 in Atlanta, Georgia, at the North American Reliability Corporation.

The targeted outcomes for this meeting were to review the premeeting comments and resolutions for Draft 6.1, continue to refine the draft revision document, and hold live recirculation votes with the intent to approve the draft revision's content to advance to preballot review, preballot preparation, and then balloting by the IEEE Standards Association.

The P1547 working group voted on the criticality of topic areas to help prioritize the discussion. Based on this prioritization, a full revision to Draft 6.1 was iteratively updated, and recirculation votes were taken live at the meeting on versions Draft 6.2 through Draft 6.6. Results from each 
recirculation voting are shown in Table 2. Draft 6.6 received adequate "yes" votes from the working group ( $>66 \%$ ) to achieve approval of the draft's content for preballot review and ballot preparation by the IEEE Standards Association in coordination with the working group. Not all priority topics were reviewed at the meeting, however, so the working group members directed that the comments received up to and through the meeting be considered for the creation of Draft 6.7 , to be recirculated (in approximately 2 weeks) for one more round of voting to reaffirm approval.

Table 2. Results from Recirculation Voting

\begin{tabular}{|c|c|c|c|c|c|c|}
\cline { 2 - 7 } & D6.1 VOTE & D6.2 VOTE & D6.3 VOTE & D6.4 VOTE & D6.5 VOTE & D6.6 VOTE \\
\hline TOTAL VALID & 84 & 85 & 85 & 85 & 85 & 85 \\
\hline \hline YES & $64 \%(49)$ & $64 \%(50)$ & $65 \%(50)$ & $65 \%(50)$ & $69 \%(54)$ & $89 \%(70)$ \\
\hline NO & $36 \%(27)$ & $36 \%(28)$ & $35 \%(27)$ & $35 \%(27)$ & $31 \%(24)$ & $11 \%(9)$ \\
\hline \hline ABSTAIN & $10 \%(8)$ & $8 \%(7)$ & $9 \%(8)$ & $9 \%(8)$ & $8 \%(7)$ & $7 \%(6)$ \\
\hline \hline QUORUM & MET & MET & MET & MET & MET & MET \\
\hline APPROVAL & FAILED & FAILED & FAILED & FAILED & MET & MET \\
\hline STATUS & REJECTED & REJECTED & REJECTED & REJECTED & APPROVED & APPROVED \\
\hline
\end{tabular}

After the meeting, the Comment Review Team finalized the changes and recirculated the draft for balloting. The changes were approved by the working group with more than $90 \%$ approval, thus enabling the next step of document preparation for the IEEE Standards Association public balloting. This successfully met the Year 2 go/no-go requirement for completion of all the Phase 2 milestones and successful IEEE Std P1547 initial ballot ( $>75 \%$ agreement).

\section{Completion of IEEE Std P1547 Final Public Ballot}

Working Group Chair Narang, along with the P1547 officer team, finalized the document for submission to IEEE for sponsor balloting (Subtask 3.1.1). The sponsor balloting process involved a preliminary mandatory editorial review, an editorial and legal review by IEEE that was completed in early May 2017.

The IEEE Std P1547 public sponsor ballot opened on May 19, 2017 and extended through June 18, 2017. The ballot pool had robust participation, with 389 balloters. The ballot resulted in 63 negative ballots, 225 affirmative ballots, and 21 abstentions and generated more than 1,500 comments. The initial ballot approval rate was $78 \%$ affirmative.

The next step in the process was for the Ballot Review Team to respond to the comments toward the goal of furthering consensus among the balloters. Under the leadership of ACCEL team member Narang, the Ballot Review Team held initial meetings and began comment resolution in July 2017.

The ballot was recirculated four more times, and each resulted in improvements to the document and a corresponding increase in approval votes. The last recirculation, completed on December 29,2017 , resulted in an approval vote of 93\%, as shown in Figure 1. In total, more than 1,800 ballot comments were resolved total across all ballot circulations. 


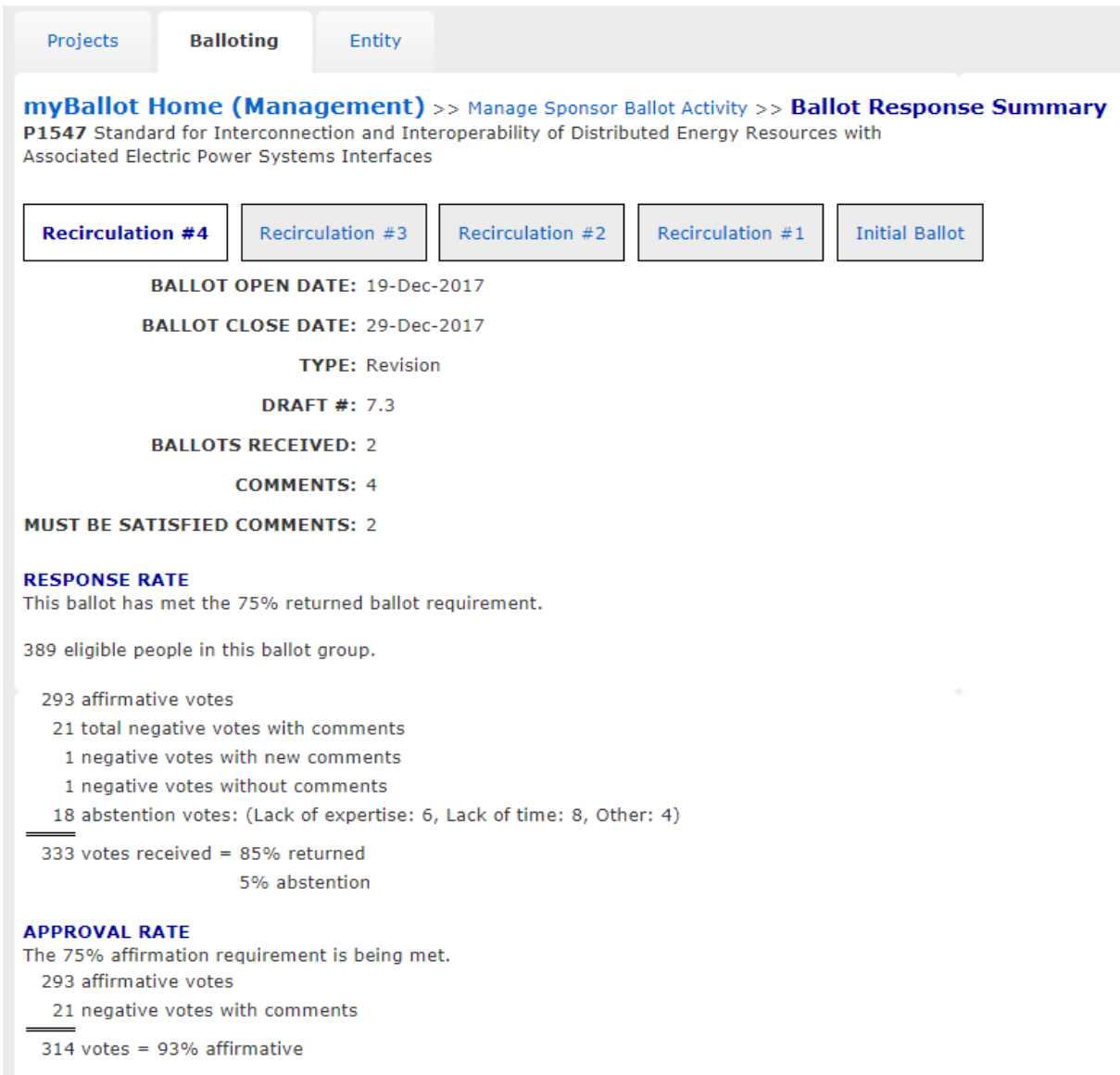

Figure 1. Final P1547 ballot recirculation results (R4, December 29, 2017)

Following this successful ballot, ACCEL team member Narang worked with key working group officers to finalize the draft for submission to the IEEE review committee for consideration to publish. Approval was granted, and Narang and working group officers worked with IEEE editors to finalize the document in early 2018. IEEE Std 1547-2018 was published in April 2018.

\section{Establishment of New Grid-Support Function Conformance Testing Procedures}

\section{Establishment of New Conformance Test Procedures for Grid-Support Functionalities in UL 1741 SA}

UL 1741 is the national standard test procedure covering safety and grid interconnection performance for grid interactive inverters. It directly references the type tests in IEEE Std 1547.1 to validate grid interconnection functionality, and thus certification to UL 1741 is the primary way that DERs are recognized as conforming to IEEE Std 1547. As an interim solution while IEEE Std 1547 and 1547.1 were being revised, an amendment to UL 1741 was developed to allow certification of certain grid support functionality needed in California and Hawaii. The amendment to UL 1741, known as UL 1741 Supplement A (UL 1741 SA), which represents the first national test standard for grid-supportive DERs, was expected to be complete around the time of the start of the ACCEL project. High stakeholder interest, however, led to a larger-than- 
expected number of comments on the standard, so the first task of the ACCEL team was to contribute to the completion and approval of that standard.

The initial UL 1741 SA ballot responses were 39 affirmative, 9 negative, 2 abstentions, and 30 not returned. The working group met three times per week to address the 224 comments that were received. Consensus was reached, and the draft was recirculated.

ACCEL members (Gonzalez and Coddington) contributed to updating the UL 1741 SA draft. The draft was submitted to the UL Standards Technical Panel (STP) with comments returned in late 2015 and early 2016. About 450 comments were received from the STP; most were technical, with some editorial. The ACCEL team contributed to resolving numerous UL 1741 SA comments. Overall, there were many more comments received than originally anticipated, and as a result the UL timeline for this work exceeded the planned deadline by 9-12 months. That outcome resulted in additional ACCEL resources expended on UL 1741 SA and also delayed the ACCEL team's use of the UL 1741 SA approved procedures as a starting point for the development of the P1547.1 test procedures.

The UL 1741 STP working group weekly teleconferences included establishing testing requirements for the autonomous implementation of DER inverter advanced functions. During Q1, ACCEL team members contributed to the STP working group teleconferences to develop the test procedures for the draft. The following identify the technical topics directly addressed by the ACCEL team's participation:

- Low- and high-voltage and frequency ride-through were topics of discussion among utility, industry, and test laboratories (national labs and nationally recognized testing laboratories).

- Voltage and frequency regulation. Voltage regulation discussions included commanded power factor operation, volt-VAR control, and commanded reactive power functions.

- The frequency regulation function was debated and drafted primarily as the frequencywatt droop function. Within UL 1741, this is optional because it was optional for California Rule 21 at the time; it is now required.

- Ramp rates. There was much discussion on when to implement slow ramp operation and, whether or not ramp-down is needed, even for shutdown for maintenance situations.

- An ACCEL member (Gonzalez) led the UL 1741 SA STP unintentional islanding section that met for 1.5 hours each week for 8 weeks in late 2015. Specifically, the unintentional islanding section included much discussion on the number of tests to run and the combination of tests to run as well as additional discussion on unintentional islanding testing without voltage and frequency regulating functions enabled but with voltage and frequency ride-through enabled.

The completion and publication of UL 1741 SA allowed the ACCEL team to fully focus on the core tasks and milestones. 


\section{Establishment of New Conformance Test Procedures for Grid-Support Functionalities in IEEE P1547.1 Draft}

In Year 1, ACCEL team members (Basso, Chakraborty, and Hoke) worked with the other vice chairs (Zgonena, UL; Schoder, Florida State University; Enayati, National Grid) to set up the detailed organization for the IEEE P1547.1 (Milestone 1.1.2., Milestone 2.1.2). The structure included 13 subgroups responsible for developing test procedures and requirements for type testing, production testing, DER evaluations, commissioning tests, and periodic testing under P1547.1. These tests were performed to confirm that the interconnection and interoperation functions of equipment and systems interconnecting DERs with the electric power system conform to IEEE Std 1547.

A detailed scope for each of the subgroups was developed by the P1547.1 officers and then introduced to the subgroup chairs. The initial subgroup structure is given in Table 3 . The subgroup chairs included various non-ACCEL-project industry partners (designated by their initials) who were successfully recruited to take on more enhanced roles for standards development.

Table 3. Structure of P1547.1 Subgroups (as of June 2016)

\begin{tabular}{lll}
\hline Subgroup Topics & Officer & Subgroup Chair(s) \\
\hline General requirements & S. Chakraborty & S. Chakraborty \\
Overall document & S. Chakraborty & S. Chakraborty \\
Abnormal voltage and frequency conditions tests & T. Zgonena & $\begin{array}{l}\text { J. Berdner, M. Algrain, } \\
\text { J. Boemer }\end{array}$ \\
Voltage and frequency regulation tests & T. Zgonena & B. Lydic, J. Ehlmann, \\
Unintentional islanding tests & T. Zgonena & S. Gonque \\
Power quality tests & T. Zgonena & R. White, S. Hong \\
Soft-start/ramp -ate tests & T. Zgonena & - \\
Synchronization tests & T. Zgonena & M. Algrain \\
Modeling and simulation & K. Schoder & - \\
Hardware-in-the-loop tests & K. Schoder & K. Schoder \\
Interoperability tests & K. Schoder & B. Seal, R. Fox \\
Installation, commissioning, and periodic tests & B. Enayati & M. Siira, W. Stec \\
$\begin{array}{l}\text { DER microgrid capabilities and microgrid } \\
\text { interconnection devices }\end{array}$ & B. Enayati & C. Rowe \\
\hline
\end{tabular}

ACCEL team members worked with IEEE to develop policies and procedures for the IEEE P1547.1 working group that will provide a fair framework for timely completion of the standards development activities. The P1547.1 working group unanimously approved the policies and procedures during the June 2016 meeting. IEEE's collaboration and productivity tool, iMeetCentral, was used by ACCEL team members to maintain the IEEE P1547.1 work space and for collaboration among working group members. Additionally, the ACCEL team updated the 
IEEE Standards Coordinating Committee 21 P1547.1 Grouper website and set up the listserv for IEEE P1547.1.

ACCEL team members also worked with the other vice chairs to develop a timeline to ballot for IEEE P1547.1. This timeline was aggressive considering the large number of new material being included in P1547.

UL 1741 SA (supported by ACCEL team members Coddington, Gonzalez, Hoke, and Chakraborty) was heavily leveraged for developing test procedures for some of the advanced functions.

ACCEL team members (Basso, Chakraborty, and Hoke) developed logistics and an agenda for the second meeting of the P1547.1 working group. The meeting was colocated with the IEEE P1547 working group meeting and was held in Portland, Oregon, on June 16, 2016, at Portland General Electric's headquarters. The working group meeting had 81 participants and was well attended by a diverse set of stakeholders, including manufacturers, utilities, testing laboratories, the U.S. Department of Energy, national laboratories, and consultants.

The targeted outcome for the meeting was to introduce the subgroups for drafting the full revision to IEEE Std 1547.1-2005/2015 and kick off the drafting process. ACCEL team member (Chakraborty) chaired the 1-day working group meeting for P1547.1. To kick-start the subgroup writing activities in the presence of the officers, breakout sessions were designed. Seven P1547.1 subgroups held breakout sessions to begin discussions of the material they would draft. Following the subgroup breakout sessions, a chair or cochair from each subgroup summarized the discussion in each breakout session for the full working group. The subgroup kick-off was followed by various electronic communications and teleconferences to begin drafting the revised standard.

At the June 2016 P1547.1 working group meeting, Gonzalez led the introduction of the unintentional islanding section to IEEE Std 1547.1. Robust discussions have led to further investigations in some of the working group decisions, and in most cases meetings ended in the team reaching consensus on the topics.

In addition to the overall ACCEL leadership activities, NREL researcher Chakraborty (appointed as P1547.1 chair) contributed to the first working group meeting by presenting technical insight on P1547.1. Based on his experience with the state-of-the-art interconnection requirements (such as California Rule 21, Hawaii Rule 14H, IEEE Std 1547a, and IEEE Std P1547) and experience in developing new test procedures for interconnections (such as UL 1741 SA and IEEE Std 1547.1a), the presentation focused on identifying potential updates and the need for new procedures for the P1547.1 standard.

The definitions and classifications of the tests within IEEE Std 1547.1-2005 were reviewed, and various topics or gaps were discussed that should be considered or addressed in P1547.1, including DER performance accuracy, test equipment requirements, and potential modifications or extensions of the draft of UL 1741 SA procedures as starting points to draft new or revised conformance test procedures to address the requirements of P1547. 


\section{Establishment of New Test Requirements for Interoperability and Special Interconnections in IEEE Std P1547.1 Draft}

Drafts 1, 2, and 3 of P1547.1 were completed and reviewed during Year 2 (October 2016September 2017). ACCEL team members (Chakraborty and Hoke) led two monthly calls of the working group leadership (officers and subgroup chairs) to guide progress of each of the subgroups, and each subgroup held weekly calls to develop content. Hoke coordinated with the German standards development organization FGW to obtain a copy of the German conformance test procedure guidelines, FGW TR3, for the P1547.1 working group.

In Spring 2017, the general requirements subgroup, chaired by Chakraborty, was formed under P1547.1 working group. The scope of the subgroup is covered in Clause 4 of P1547.1. This clause includes test results accuracy; testing environment; measurement accuracy; and calibration of the testing equipment, product information, test reports, testing equipment requirements, and any other general requirements as required by P1547. Subgroup biweekly calls started in May, when Chakraborty gave an introductory presentation and the subgroup started working on the draft language.

Some subgroups reached near completion by the November 2017 meeting, whereas others did not. In particular, subgroups whose leaders also held leadership roles in IEEE Std P1547 were behind schedule because the leaders were focused on P1547 finalization. This challenge continued as the P1547 leadership focused on ballot resolution in late 2017. Therefore, it was not possible to achieve a nearly complete draft of P1547.1 by the November 2017 meeting and a ballot-ready draft by the March 2018 meeting, as initially planned.

The P1547.1 Working Group Chair, Chakraborty, resigned in July 2017 because of a change in employer. The Working Group Secretary, Hoke, was approved by the working group and the IEEE Standards Coordinating Committee 21 leadership to fill the chair position. Hoke recruited Jeannie Amber of National Grid to fill the secretary role.

Three P1547.1 in-person meetings were held during this budget period:

- October 25-27, 2016, in Chicago, Illinois, at ComEd

- February 28-March 1, 2017, in Atlanta, Georgia, at the North American Reliability Corporation

- June 20-22, 2017, in Phoenix, Arizona, at Salt River Project.

Summary of Technical Contributions to Requirements for Unintentional Islanding

ACCEL team member Gonzalez (Sandia) continued to lead the unintentional islanding subgroup of IEEE Std P1547.1. A subject matter expert under contract to Sandia provided expert consultation on the anti-islanding, voltage and frequency ride-through, and power quality sections of IEEE Std P1547.1.

During Year 2, the subgroup under Gonzalez's leadership developed new language that was vetted to the subgroup on a weekly basis. The subgroup discussed new test procedure language, the resistor-inductor-capacitor (RLC) islanding circuit, and equation revisions. Topic discussions included islanding circuit components that are presently under much discussion by utilities, 
inverter manufacturers, and subject matter experts. White papers were published to document the expected voltages and frequencies during a sustained islanded condition. An important contribution during this budget period was the development of new voltage and frequency ridethrough requirements in the unintentional islanding test procedures.

Changes to the RLC islanding circuit were developed to better represent real-world islanding scenarios and improve the reliability of unintentional islanding tests. Initially the circuit was represented with a single-line diagram and had no distinction between inverter and load configurations. The working group developed an RLC circuit revision that explicitly shows the actual inverter and load configuration for a wye-connected system and for a delta-connected system. Moving forward, when conducting the unintentional islanding evaluation, there will be no ambiguity on load configurations.

Discussions on RLC load representation of motor loads resulted in changes to the quality factor, which is the stored energy-to-load ratio of the circuit, of the RLC circuit. The quality factor, originally set to a value of 1 , was modified as a means to compensate for the inertial characteristics of motor loads. Based on this need, the quality factor characteristics of the RLC circuit were expanded to a range from 0.95 to 1.5 (previously 1.0) to provide more achievable testing conditions.

An important area of discussion included the RLC representation of islanded load conditions and whether there should be different testing procedures for different unintentional islanding algorithms.

In an effort to streamline this procedure, the unintentional islanding subgroup developed an alternative method of demonstrating compliance that reduced the number of unintentional islanding testing by $57 \%$. This required verification that the tuned RLC circuit was correctly implemented, which was done through demonstration that a sustained island could be achieved if the island detection algorithm was turned off, and upon re-enabling the island detection function, the equipment under test would detect the loss of the utility and would cease to energize and trip within the 2 seconds. While demonstrating the correct implementation of the tuned RLC circuit is required, it was decided the full 10+ unintentional islanding tests per test sequence were still needed for EUTs with grid support functionality, to make the tests more rigorous.

The subgroup also introduced a communications-based unintentional islanding test procedure that uses a permissive signal.

\section{Preparation for IEEE Std P1547.1 Public Ballot}

During Year 3 (October 2017-September 2018), the ACCEL team continued to drive the working group to complete the P1547.1 test procedures (Milestone 3.1.1). IEEE Std 1547-2018 was published in April 2018, freeing up key working group personnel to focus on IEEE Std 1547.1.

The leader of the voltage and frequency ride-through subgroup (a key component of 1547.1) resigned during this period because of a lack of employer support. To accelerate this subgroup, which had fallen behind, Hoke recruited a new subgroup leader and supported him with a subcontract under ACCEL. Under the new leadership, this subgroup made significant progress 
during 2018, drafting several new tests from scratch, including a more rigorous low-voltage ridethrough test that better represents real-world voltage sags while allowing for flexibility in how tests labs run the test. This flexibility is needed to make the test feasible for the wide range of DERs covered by 1547.1, from microinverters to megawatt-scale inverters and even multimegawatt synchronous machines. In addition, Hoke drafted a new phase-jump ride-through test for the voltage and frequency subgroup, following the same principles of rigorously verifying the DER ride-through capability while ensuring that the test is applicable to the full range of DERs.

Hoke also assumed leadership of the general requirements subgroup, holding weekly 1.5-hour meetings for several months to update the P1547.1 general test requirements. The general requirements subgroup also served as a catchall for other tests that did not fall under the scope of other subgroups, including topics such as persistence of DER settings, dynamic limitation of maximum DER active power, open-phase condition testing, temperature stability testing, and interconnection integrity testing.

The topic of reporting DER test results in a uniform format arose as a key aspect of confirming DER compliance to 1547 during this budget period. Hoke and the working group leadership initiated a subgroup on results reporting, also led by a subcontractor to ACCEL. The results reporting subgroup coordinated with a number of outside organizations - including the Electric Power Research Institute (EPRI), SunSpec, various utilities, and various DER manufacturersdevelop a uniform, machine-readable, test results reporting format that will facilitate faster and more automated interconnection of DERs while ensuring utilities can rely on the DERs to perform as expected.

A 1547.1 subgroup on the prioritization of DER responses was also initiated during this budget period to ensure that the many requirements of 1547 follow a proper and predictable precedence. This subgroup was initially led by an ACCEL subcontractor and was later taken over by a representative of the inverter industry.

ACCEL team member Shazreen Meor-Danial is working closely with a subgroup on installation, commissioning, and periodic testing and subgroup leaders to develop material outlining the requirements and recommendations for performing DER design and installation evaluations as well as commissioning tests. The scope of this subgroup covers a broad range of applications, from small residential DERs to larger DER systems containing arrays of DER units and supplemental devices required to achieve the IEEE Std 1547-2018 requirements. The group considered feasibility and challenges in performing any verifications in the field and yet ensured that the installed system fulfills the requirements. The subgroup continues to address comments and incorporate feedback from the other subgroups/clauses.

In addition to multiple weekly subgroup teleconferences (typically 6-10 per week), the P1547.1 working group held three in-person meetings, each for 2.5 days, organized and lead by Hoke. For each in-person meeting, a new draft of P1547.1 was compiled and distributed for review and comment.

Going into the last quarter of the third and final year of the project, the working group's goal was to approve the P1547.1 Draft 7 during a final in-person meeting in October 2018 (after the end of 
the budget period). In preparation, a formal comment period was initiated in September 2018. Delays in the finalization of some subgroup materials, however, led Hoke and the working group leadership to agree to extend the comment period through early fall 2018 and set a new goal of finalizing the content and gaining working group approval by late 2018 or early 2019 . Based on that, Hoke and the working group leadership agreed to a new timeline for publication, as shown in Table 4.

Table 4. Proposed Timeline to Ballot for P1547.1

\begin{tabular}{ll}
\hline Dates & Activities \\
\hline October 3, 2018 & Working group comments on Draft 7 due \\
October 9-11, 2018 & Working group meeting, review and discuss comments on Draft 7 \\
October-November 2018 & Subgroups and comment review team address Draft 7 comments \\
December 2018 & Officers prepare Draft 8 for working group review and ballot \\
January 2019 & Working group ballot and comment on Draft 8 \\
Winter 2019 & Working group approval to send P1547.1 to IEEE Standards \\
Spring 2019 & Association for sponsor ballot \\
Summer-Fall 2019 & IEEE Standards Association sponsor ballot of P1547.1 \\
Late Fall 2019/Winter 2020 & Ballot comment resolution and recirculation \\
\hline
\end{tabular}

In Fall 2018, the working group leadership and subgroups are working to address the 1,308 comments received during the working group review of Draft 7 . Hoke formed a comment review team comprising working group officers, subgroup chairs, and key representatives of stakeholder groups to address comments that cannot be resolved at the subgroup level. The comment review team will also become the ballot review team when the IEEE Standards Association sponsor ballot begins in 2019. The draft is currently 260 pages. Finalizing this extensive and technical document will require several more months of diligent effort on the part of the entire working group.

\section{Laboratory Validation of Requirements and Conformance Testing Procedures}

To ensure that the new tests being developed in IEEE Std P1547.1 were feasible, reliable, and repeatable, NREL and Sandia executed the draft test procedures on a variety of inverters. This allowed the labs to provide feedback to the subgroups writing the tests, resulting in improved test procedures.

Subtasks and milestones under this project also provided laboratory validation of the testing procedures for the IEEE and UL standards (IEEE Std 1547a, UL 1741 SA, and IEEE Std P1547.1) (Subtask 1.1.2, Subtask 2.1.2). The ACCEL team provided focused P1547.1 (testing procedures) leadership and increased development and validation of conformance testing that focused on the new functions and capabilities. 


\section{Sandia Test Equipment and Setup}

Figure 2 shows the one-line test configuration for Sandia's testing. The sources and EUT are located within $50 \mathrm{ft}$ of one another. A LabView and National Instrument-based data acquisition system provides $3-\mathrm{Hz}$ steady-state monitoring and oscillatory data capture.

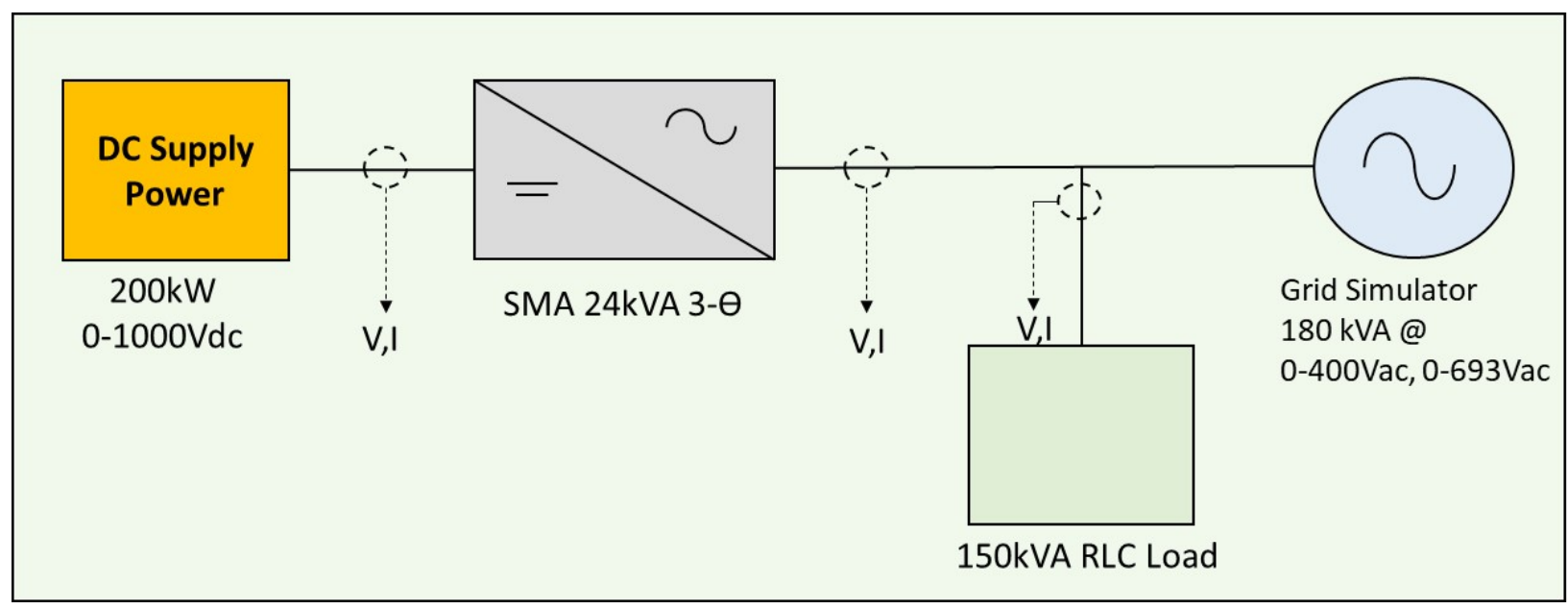

Figure 2. Sandia's test configuration

At Sandia, the following equipment was used to provide repeatable assessments of capabilities and performance. For testing purposes, PV was either provided using actual PV from a SolarWorld solar array or, more commonly, supplied using the TerraSAS 100-kW PV simulator (see Figure 3, left). This PV simulator provides a maximum power point tracking (MPPT) compatibility DC input that works well with most inverters and allows experiments to be assessed at different operating conditions, i.e., MPPT enabled or equipment under test operating at a current limit.

An AC simulator (see Figure 3, right) provided the external stimulus for autonomous voltage and frequency regulating functions to be assessed and to assess the responsiveness of voltage/frequency ride-through capabilities. This AC simulator was fully programmable to provide events for the inverter to respond to and also transferred power back to the simulated utility. 


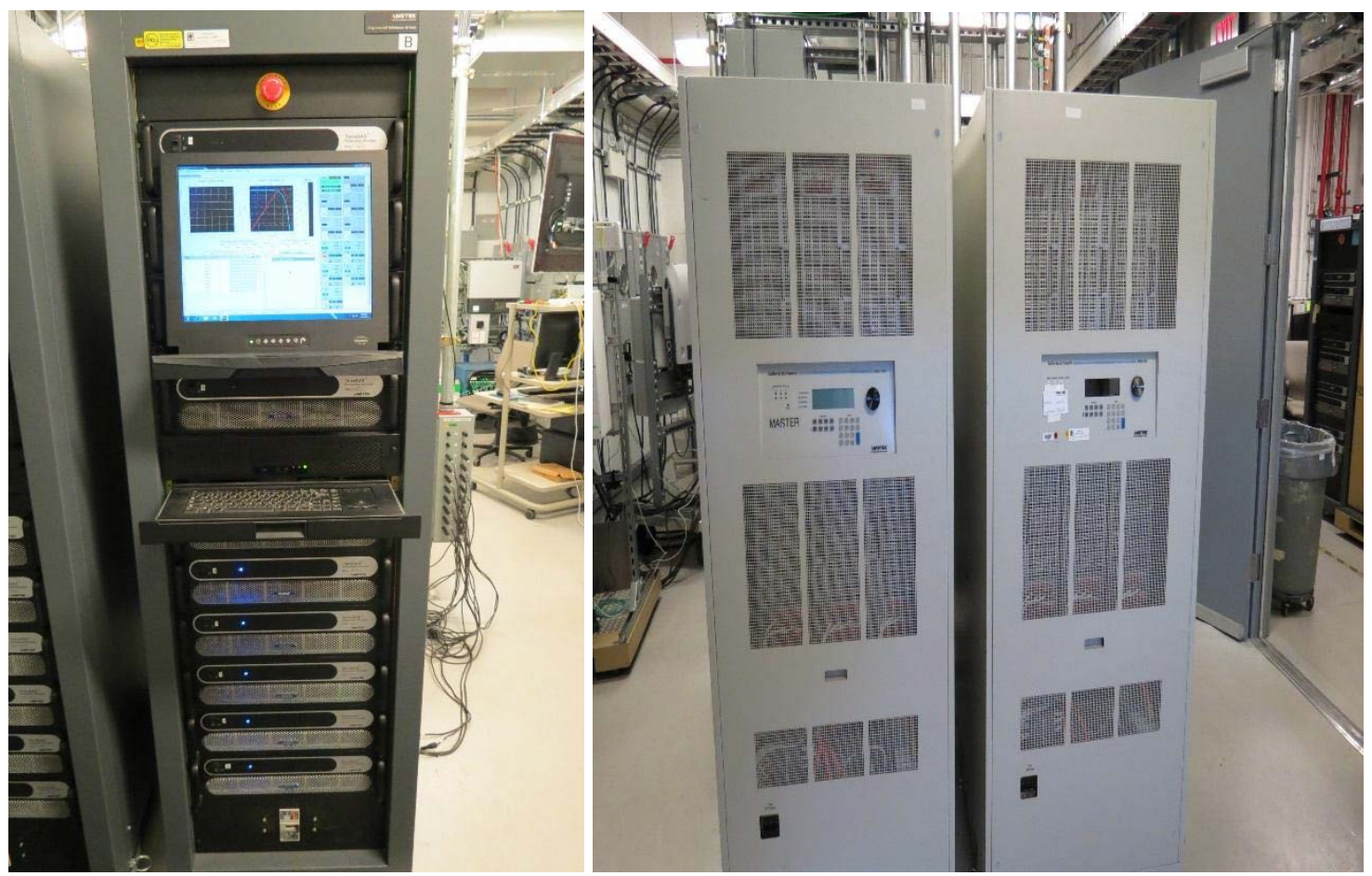

Figure 3. Lab equipment at Sandia for evaluating conformance test procedures: TerraSAS100-kW PV simulator (left); Ametek 180-kVA AC simulator (right). Photos courtesy of Sandia National Laboratories

For these evaluations, the ride-through and the voltage and frequency regulation test procedures were taken from the UL 1741 SA document. Work for the first year consisted of validating procedures for unintentional island testing of a residential single (split-phase) inverter and small three-phase commercial inverters.

\section{NREL Test Equipment and Setup}

Figure 4 shows the test setup developed for this project. All the equipment shown in this setup is located at different locations in the Energy Systems Integration Facility at NREL. The connections among this equipment were established using the Research Electrical Distribution Bus. The Research Electrical Distribution Bus is the backbone of the Energy Systems Integration Facility electrical test system, and it provides the means to connect different fixed equipment and equipment under test located throughout the facility. Electrically operated switches in the bus allow a high degree of flexibility on test network configuration. 


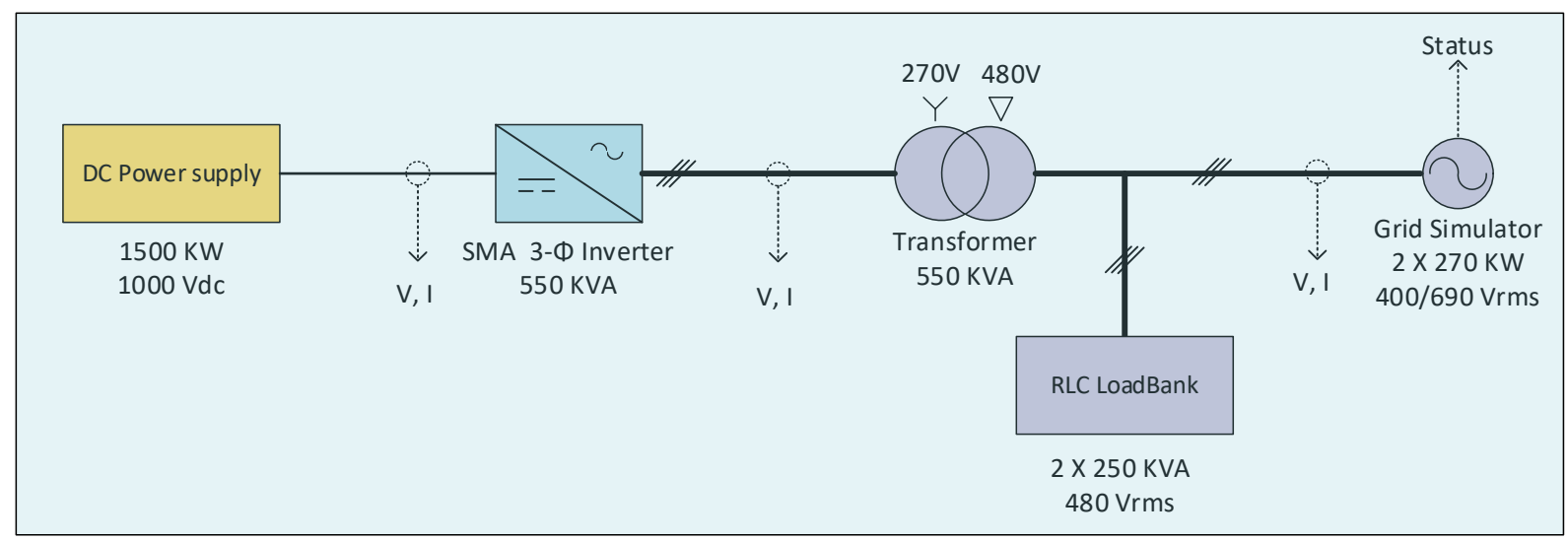

Figure 4. NREL test setup

This test setup took advantage of NREL's 1-MW grid simulator, 1-MW PV simulator, and 1MW load bank. And evaluation of conformance test procedures focused on tests most likely to be problematic specifically for large-scale DERs, such as ride-through tests, which require very high power and voltage slew rates. Figure 5 shows some of the equipment used in this test setup. 


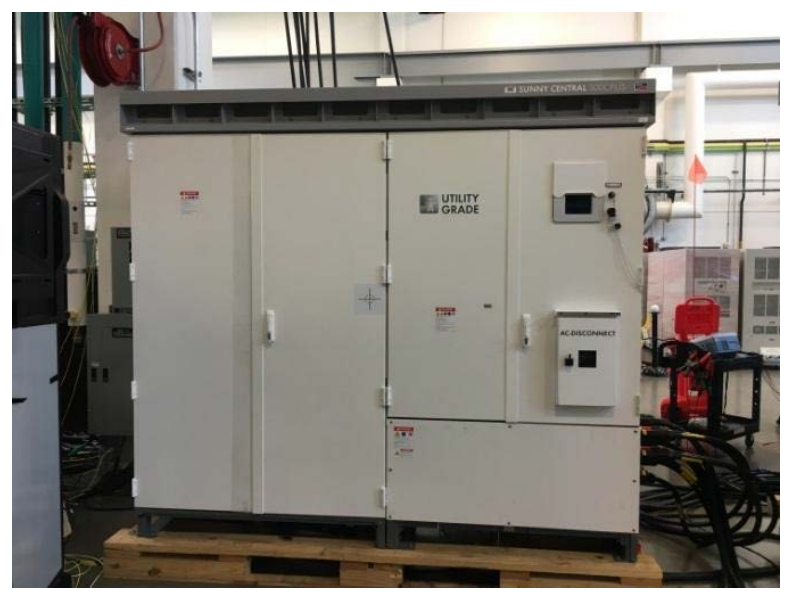

(a)

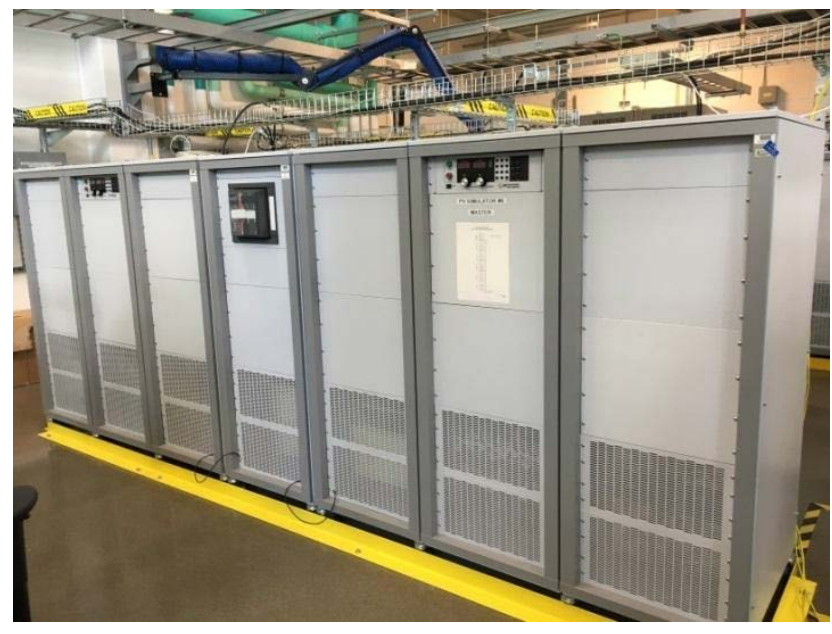

(c)

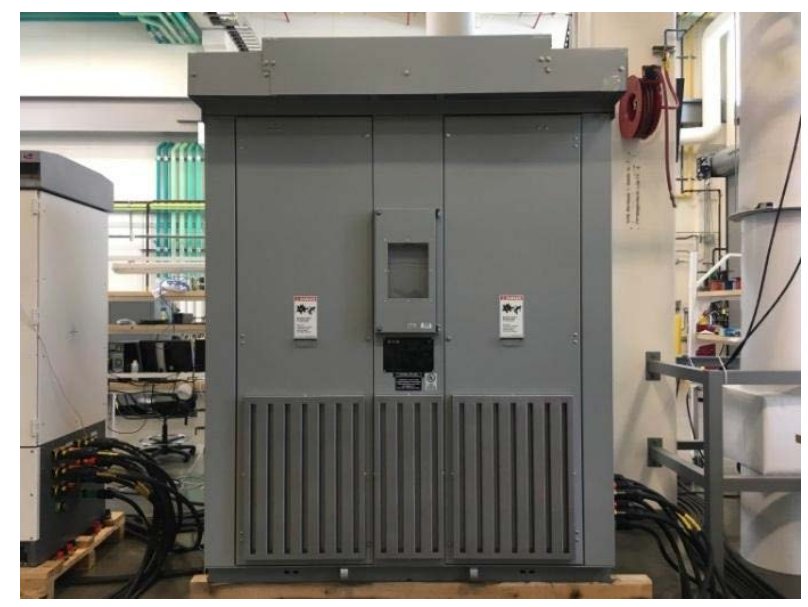

(b)

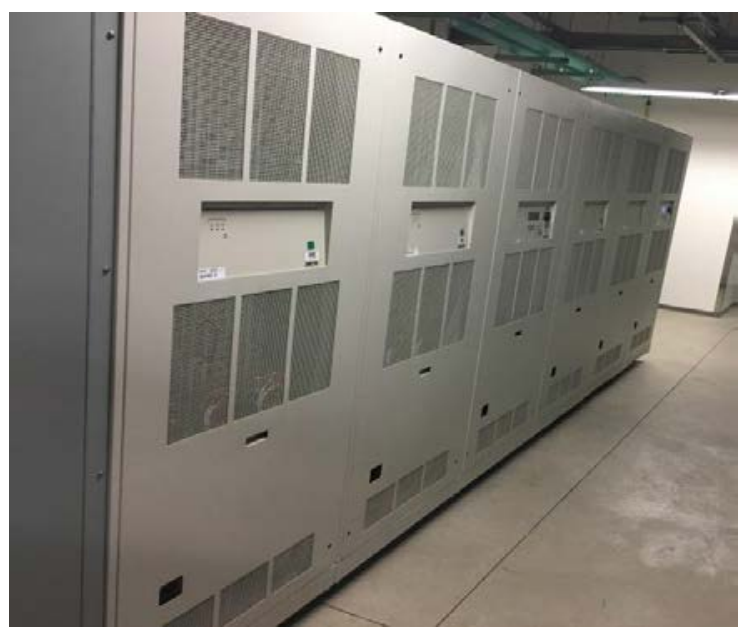

(d)

Figure 5. Inverter/transformer set: (a) 550-kVA inverter, (b) 550-kVA transformer, (c) two MagnaPower DC power supplies, (d) section of the Ametek grid simulators/power supplies. Photos courtesy of Rasel Mahmud

\section{Confirmation of New Testing Procedures for PV Inverter Testing of Grid-Support Functionalities in IEEE Std P1547.1 (Addressed per Autonomous Response)}

In Year 1, the team successfully validated the 1547a grid function and unintentional islanding test procedures on single-phase residential and small commercial inverters. The basis for testing procedures in Year 1 was UL 1741 SA, as intended for autonomous response grid-support functions. In Year 2 and Year 3, NREL went on to validate these for larger three-phase inverters. In Year 2 and Year 3, NREL and Sandia also incorporated the use of standardized communications protocols to validate that measured inverter behavior matched the intent of communicated commands, helping ensure interoperability of DERs. Throughout the testing, the team provided valuable feedback on emerging requirements and test procedures as they were developed for 1547.1. 


\section{Evaluation of Conformance Test Procedures at NREL}

Because of late funding during the first project year, and because of several ongoing lab testing projects at the time of the ACCEL funding arrival, NREL was able to allocate only a small amount of engineer time to ACCEL testing in FY 2016. To better leverage the very limited labor time available for ACCEL in FY 2016, NREL leveraged an ongoing project with HECO on advanced inverter testing. NREL developed an agreement with HECO and four inverter vendors to perform volt-VAR testing using the UL 1741 SA draft test procedure under ACCEL funding in addition to HECO-funded tests of volt-watt control, voltage ride-through, frequency ridethrough, ramp-rate control, soft-start, and fixed power factor control. As part of that agreement, HECO and the inverter manufacturers agreed that results and lessons learned from both the ACCEL-funded volt-VAR testing and HECO-funded testing of the six other functions could be used to inform the UL and IEEE Std P1547.1 test development.

The four PV inverters used to evaluate the UL 1741 SA test procedure included two sets of microinverters; a single-phase PV inverter; and a three-phase, 480-V, 20-kVA commercial inverter. The manufacturers included two that are well established, one up-and-coming manufacturer, and one relative newcomer to the market. Two of the manufacturers are from the United States, one is from Europe, and one is from Asia. Thus, lessons learned from this testing helped ensure that the standardized test procedures are applicable to a wide range of device classes.

The testing of microinverters was particularly important for volt-VAR control because microinverter PV systems in the field nearly always contain many (often dozens or more) inverters. NREL's past testing has shown that such systems behave differently from systems containing one or a small number of inverters.

The testing described here differs from testing performed by other labs, including Sandia, in that the "source requirements document" used with the UL 1741 SA test procedure was Hawaii Rule $14 \mathrm{H}$. Thus, this testing helps address the significant utility concern that UL 1741 SA and IEEE Std P1574.1 be applicable not only to the large market governed by California Rule 21 but also to smaller markets and smaller utilities such as HECO, which often have significantly different interconnection requirements. NREL's testing largely confirmed the validity of the UL 1741 SA tests.

In the second year of the project, the NREL team began evaluation of key UL 1741 SA tests against a large (550-kVA) commercial inverter to ensure that the conformance test procedures can be applied to a set of inverter technologies that is as wide as possible.

Although such testing using a 550-kVA inverter is more resource intensive than testing smaller inverters, it fills an important gap to confirm that test procedures are valid across a wide range of DER sizes and will help ensure that the tests are valid and reliable for central inverters, complementing Sandia's work with single-phase and three-phase string inverters.

Note that the 550-kVA inverter under test was manufactured in 2014, prior to the publication of UL 1741 SA (and certainly before the current IEEE Std P1547 draft was developed). NREL engineers installed updated inverter control firmware that provided improved functionality for grid-support functions. Neither the inverter nor the firmware was certified to UL $1741 \mathrm{SA}$, 
however, which was not yet required in any jurisdiction until September 2017. Therefore, any tests that the inverter "failed" should not be taken to reflect poorly on the inverter, nor should they be taken to reflect poorly on the test procedure. The objective here was to test the test procedures, not to test the inverter compliance.

In the third project year, NREL testing focused on the characterization of inverter responses to faults on the grid to which the inverter is connected. Standardized type-testing of such responses is a key new component of P1547.1 and a key hurdle for many utilities in interconnecting high levels of DERs. This testing used both the 550-kVA utility-scale inverter and a smaller 20-kVA, three-phase string inverter. A paper describing the results of this testing, accompanied by theoretical analysis and a proposed method for modeling inverter fault responses, is in the final stages of preparation.

The Sandia team evaluated residential and small commercial inverters pertaining to the draft language of IEEE Std P1547.1 sections that are available. The draft fault current characterization test procedure (Subclause 5.18) uses an apparatus configuration that defines the shunt and series impedances that result in the source voltage staying within $5 \%$ of nominal operating voltage and the voltage at the inverter terminals sagging to less than $5 \%$ of nominal operating voltage. At Sandia, the simulated short-circuit configuration was evaluated using a simplified circuit, and the inverter short-current contributions were investigated. With the three-phase and single-phase inverters connected to the AC simulator, three-phase symmetrical and asymmetrical line-toground faults were simulated by implementing a voltage sag on the inverter terminals and capturing the current contributions from the inverters. The level of severity will determine the duration the inverter can feed the fault, per utility interconnection standard requirements. For IEEE Std 1547-2018 Category II DERs, a fault resulting in a voltage sag to $\geq 30 \%$ of nominal requires the equipment under test to ride through the event and continue to energize the utility. For IEEE Std 1547-2018 Category III DERs, for a voltage sag to $>50 \%$ of nominal voltage, the DER must cease to energize the utility within $83 \mathrm{~ms}$; therefore, the short-circuit current will not last longer than five cycles.

The Sandia test results confirm the applicability of the proposed P1547.1 fault current characterization test for three-phase and single-phase DERs. Results were published in an IEEE Photovoltaics Specialists Conference paper in 2018 (Gonzalez 2018).

NREL also conducted inverter fault response tests to inform the development of the P1547.1 draft test procedure. NREL's tests were intended both to validate draft test procedures and to more thoroughly explore and characterize inverter fault responses to determine the minimum amount of testing that could provide utilities with sufficient information on inverter fault responses. NREL's tests found that inverter fault responses vary widely and that they are not easily summarized by a simple model. Perhaps not surprisingly, many current inverter fault responses do not conform to the newly published requirements of IEEE Std 1547-2018. NREL has drafted a paper providing an analysis of inverter fault responses including a proposed parameterized inverter fault response model. The analysis and simulation results are validated with lab test results. The paper is expected to be published in 2019. 


\section{Confirmation of Testing Procedures for Unintentional Islanding Scheme(s) with Full Suite of Grid-Support Functions Enabled (IEEE Std 1547a Settings)}

In the second project year, Sandia completed the validation of the test procedures for unintentional islanding testing with autonomous 1547a grid-support functions enabled as applied to residential and small commercial inverters. The team noted areas of the procedure that require extra care during execution, such as configuration settings, and reported these findings to UL and relevant P1547.1 subgroups.

NREL increased the applicability of the test procedures by commencing testing on a large commercial inverter $(500 \mathrm{~kW})$. Several lessons learned from testing were reported to the P1547.1 subgroups responsible for the relevant tests.

Lab tests of both residential-scale and utility-scale inverters have confirmed draft UI test procedure functionality.

\section{Confirmation of New Testing Procedures for PV Inverter Conformance to Interoperability Requirements (Test via Communications)}

At the time of the project start, UL 1741 SA did not explicitly address interoperability testing, so the start of the interoperability testing subtask was delayed (Milestone 1.1.2, Milestone 2.1.1, Milestone 3.1.2). NREL and Sandia instead established an approach for drafting new test procedures related to the P1547 draft interoperability requirements and P1547.1 draft tests.

ACCEL team members at Sandia validated the test procedures for P1547.1 PV grid-support functions implemented via communications on single-phase residential and small commercial three-phase inverters. ${ }^{3}$ NREL began validating test procedures for commercial three-phase inverters at NREL's Energy Systems Integration Facility.

In Year 3, Sandia implemented a Kitu Systems Inc. IEEE 2030.5 client and server communication system to DER equipment. The device-level client is an Internet of Things solution for electric vehicle charging and DER management, and similar solutions are likely to appear in California soon. The system offers a suite of communication solutions for utilities, DER aggregators, solar providers, and inverter manufacturers and comprises a Kitu 2030.5 server, a WiFi access point, and a Raspberry Pi IEEE 2030.5-to-Modbus client. The server and associated graphical user interface allow the user to send commands to the inverter(s) via a profile that is time-dependent. The WiFi access point establishes communications between the server and the clients, and the Raspberry Pi interface provided communications to the inverter(s).

Interoperability assessments continue with SunSpec Modbus commands that control the operation of the inverter. The commands place the inverter in the specified active power level, specified power factor, and active/reactive power priority volt-VAR mode, and the interoperability script assesses the accuracy of the setting and conducts a compliance assessment utilizing manufacturer-specified accuracy information.

\footnotetext{
${ }^{3}$ See Johnson et al. (2018).
} 


\section{Conclusions and Next Steps}

\section{Significant Accomplishments}

- Contributions to the publication of UL 1741 SA (published in September 2016)

- ACCEL members (S. Gonzalez and M. Coddington) contributed to updating the UL 1741 SA draft through participation in the initial UL 1741 STP working group weekly teleconferences, which included establishing testing requirements for autonomous implementation of the DER inverter's advanced functions. ACCEL team members also participated in the STP comment resolution (about 450 comments were received from the STP; most were technical, with some editorial). Overall, there were many more comments received than originally anticipated, and as a result the UL timeline for this work exceeded the planned deadline by 912 months. That outcome resulted in more ACCEL resources expended on UL 1741 SA and also delayed the ACCEL team's use of the UL 1741 SA approved procedures as a starting point for the development of the P1547.1 test procedures.

- Leadership and technical contributions to the publication of IEEE Std 1547-2018

- ACCEL team leadership and direct technical involvement in the working groups contributed to the successful development, balloting, and publication of IEEE Std 1547-2018. This was a major revision to interconnection procedures representing the consensus of hundreds of individuals from a broad spectrum of stakeholder groups. The revised standard will have significant impacts around the United States and the world by ensuring that DERs help maintain grid reliability.

- Dissemination of lessons learned during laboratory validation of test procedures

- The objective of testing at Sandia and NREL was to evaluate the testing procedures prescribed by UL 1741 SA and, later, the draft IEEE Std 1547.1. During the project, the ACCEL team provided periodic updates on lessons learned from testing to the IEEE Std P1547.1 working group, typically through the appropriate subgroups. In addition, ACCEL team members A. Hoke and S. Gonzalez presented on these lessons learned from testing and others at the June 2017 IEEE Std P1547.1 in-person meeting and other forums.

- Leadership and technical contributions to IEEE Std 1547.1 draft

- The IEEE Std P1547.1 content is largely complete and is in the final editing stages before being submitted to the working group for approval to go to IEEE Standards Association public ballot. Draft 7 was circulated in September 2018 for formal comments. Working group leadership and the comment resolution team addressed more than 1,300 comments. Updates were compiled into Draft 8 which is planned to be balloted at the working group level in February 2019, with a goal of going to the IEEE Standards Association ballot in Spring 2019. The publication of P1547.1 will allow the new requirements of 1547-2018 to be properly verified.

\section{Path Forward}

The ACCEL team is currently focused on leading the finalization of IEEE Std P1547.1. The draft standard is currently more than 260 pages long, an order of magnitude longer than the published 
version (IEEE Std 1547.1-2005). This content growth reflects the larger role of DERs in the electric systems of today and tomorrow and the importance that DERs properly and reliably support grid operations. The team anticipates that when 1547.1 is publicly balloted in 2019 , it will receive a large number of ballot comments. The ACCEL team will work with stakeholders and standards leadership to address the comments to achieve a high level of consensus and a well-vetted standard. It is anticipated that 1547.1 will be published in late 2019 or early 2020 .

The publication of the new and much more complex standards 1547 and 1547.1 will require significant efforts at stakeholder education to ensure that the standards are widely understood and adopted. The ACCEL team is beginning an effort funded by the U.S. Department of Energy to educate stakeholders.

The ACCEL team is also monitoring related standards development efforts, including IEEE Std P1547.2 (the application guide to IEEE Std 1547); IEEE Std P1547.9 (the application guide for energy storage DERs); and the IEEE Std P2800 and P2800.1 series, which are somewhat analogous to the 1547 series but for bulk-system-connected, inverter-based resources. The team will provide coordination of those efforts and 1547/1547.1 and technical input where needed.

In addition, it is widely acknowledged among DER and utility industry stakeholders that given the rapid growth rate of DERs and the evolving role of DERs and associated technologies, it would be wise to revise IEEE Std 1547 more frequently (but with a smaller scope of revisions) going forward. For this purpose, the ACCEL team is maintaining a growing list of topics to address in the next revision of 1547 and monitoring the possible need to revise the standard beginning sometime in the next $2-5$ years. 


\section{References}

Institute of Electrical and Electronics Engineers (IEEE). 2003. IEEE Std 1547 - IEEE Standard for Interconnecting Distributed Resources with Electric Power Systems. Piscataway, NY.

— 2005. IEEE Std 1547.1 - IEEE Standard Conformance Test Procedures for Equipment Interconnecting Distributed Resources with Electric Power Systems. Piscataway, NY.

- 2011. IEEE Std 1547.6 - IEEE Recommended Practice for Interconnecting Distributed Resources with Electric Power Systems Distribution Secondary Networks. Piscataway, NY.

Johnson, J., R. Ablinger, R. Bruendlinger, B. Fox, and J. Flicker. 2018. "Interconnection Standard Grid-Support Function Evaluations using an Automated Hardware-in-the-Loop Testbed." IEEE Journal of Photovoltaics 8, no. 2 (March): 565-571. doi:

10.1109/JPHOTOV.2018.2794884.

U.S. Energy Information Administration. 2005. Annual Energy Review 2004 (DOE-EIA03842004). Washington, D.C. https://www.eia.gov/totalenergy/data/annual/archive/038404.pdf.

—. 2012. Annual Energy Review 2011 (DOE-EIA0384-2011). Washington, D.C. https://www.eia.gov/totalenergy/data/annual/archive/038411.pdf. 


\section{Bibliography: Inventions, Patents, Publications, and Other Results}

The following standards were developed by industry with participation and leadership from the ACCEL team:

Institute of Electrical and Electronics Engineers (IEEE). IEEE Std 1547-2018 - IEEE Standard for Interconnection and Interoperability of Distributed Energy Resources with Associated Electric Power Systems Interfaces. Piscataway, NY: 2018.

-IEEE SCC21/P1547.1 Draft 7: IEEE Draft Standard Conformance Test Procedures for Equipment Interconnecting Distributed Energy Resources with Electric Power Systems and Associated Interfaces. Piscataway, NY: 2018.

- 2008. IEEE Std 1547.2 - IEEE Application Guide for IEEE Std 1547, IEEE Standard for Interconnecting Distributed Resources with Electric Power Systems. Piscataway, NY.

- 2007. IEEE Std 1547.3 - IEEE Guide for Monitoring, Information Exchange, and Control of Distributed Resources Interconnected with Electric Power Systems. Piscataway, NY.

- 2011. IEEE Std 1547.4 - IEEE Guide for Design, Operation, and Integration of Distributed Resource Island Systems with Electric Power Systems. Piscataway, NY.

- 2013. IEEE Std 1547.7 - IEEE Guide for Conducting Distribution Impact Studies for Distributed Resource Interconnection. Piscataway, NY.

- 2011. IEEE Std 2030 - IEEE Guide for Smart Grid Interoperability of Energy

Technology and Information Technology Operation with the Electric Power System (EPS), EndUse Applications, and Loads. Piscataway, NY.

- 2014. IEEE Std 1547a-2014 - IEEE Standard for Interconnecting Distributed Resources with Electric Power Systems - Amendment 1. Piscataway, NY.

UL. UL 1741 Supplement SA: Grid Support Utility Interactive Inverters and Converters.

Northbrook, IL: 2016.

The following publications were wholly or partially funded by ACCEL:

Basso, T., S. Chakraborty, A. Hoke, and M. Coddington. "IEEE 1547 Standards Advancing Grid Modernization.” IEEE 42nd Photovoltaic Specialists Conference (PVSC) (2015).

Gonzalez, S., J. Johnson, M.J. Reno, and T. Zgonena. 2016. "Small Commercial Inverter Laboratory Evaluations of UL 1741 SA Grid-Support Function Response Times." IEEE 43rd Photovoltaic Specialists Conference (PVSC) (2016): 1790-1795.

Gonzalez, S., M. Ropp, and G. Kern. "Loss of Utility Detection Capabilities for Today's Utility Interconnected Photovoltaic Inverters." $44^{\text {th }}$ IEEE Photovoltaic Specialists Conference (PVSC) (2017). 
Gonzalez, S., N. Gurule, M. Reno, and J. Johnson. "Fault Current Experimental Results of Photovoltaic Inverter Operating with Grid-Support Functionality." $45^{\text {th }}$ IEEE Photovoltaic Specialists Conference (PVSC) (2018).

Mahmud, R., A. Hoke, and D. Narang. "Fault Model for Inverter Interfaced Distributed Generators" (in review).

—. "Validating the Test Procedures Described in UL 1741 SA and IEEE P1547.1." IEEE 45th Photovoltaics Specialists Conference (PVSC) (2018).

Nelson, A., et al. Hawaiian Electric Advanced Inverter Grid Support Function Laboratory Validation and Analysis (NREL/TP-5D00-67485). Golden, CO: National Renewable Energy Laboratory, 2016. 


\section{Appendix A: Issues Encountered and Lessons Learned from Laboratory Validation of Test Procedures}

The objective of testing at Sandia National Laboratories and the National Renewable Energy Laboratory (NREL) was to evaluate the testing procedures prescribed by UL 1741 SA and, later, the draft Institute of Electrical and Electronics Engineers (IEEE) 1547.1. During the project, the Accelerating Systems Integration Standards (ACCEL) team provided periodic updates on lessons learned from testing to the IEEE Std P1547.1 working group, typically through the appropriate subgroups. In addition, ACCEL team members Hoke and Gonzalez presented on the lessons learned from testing and others at the June 2017 IEEE Std P1547.1 in-person meeting. Tim Zgonena of UL also participated, presenting on lessons learned from UL's testing experience with UL 1741 SA.

The following pages contain a table of issues encountered and lessons learned while preparing the test setup and running the tests. Abbreviations used in the table include:

\begin{tabular}{|l|l|}
\hline Abbreviation & Meaning \\
\hline IM & Inverter manufacturer \\
\hline REG & P1547.1 voltage and frequency regulation subgroup \\
\hline GR & P1547.1 general requirements subgroup \\
\hline M\&S & $\begin{array}{l}\text { P1547.1 fault current characterization subgroup (for use in modeling and } \\
\text { simulation) }\end{array}$ \\
\hline V\&F & P1547.1 abnormal voltage and frequency conditions subgroup \\
\hline UI & P1547.1 unintentional islanding subgroup \\
\hline SRD & $\begin{array}{l}\text { Source requirements document (a companion document to UL 1741 SA specifying } \\
\text { utility requirement) }\end{array}$ \\
\hline
\end{tabular}




\section{Lessons Learned from Laboratory Testing}

\begin{tabular}{|c|c|c|c|c|c|c|}
\hline $\begin{array}{l}\text { Finding } \\
\text { number }\end{array}$ & Lab & $\begin{array}{l}\text { ACCEL- } \\
\text { funded? }\end{array}$ & Lesson & Possible solution & Question(s) & Feedback to \\
\hline 1 & NREL & Yes & $\begin{array}{l}\text { UL } 1741 \text { SA volt-VAR test does not account for } \\
\text { adjustable response time }\end{array}$ & Modify test to account for response time. & & $\begin{array}{l}\text { REG, UL } 1741 \\
\text { STP }\end{array}$ \\
\hline 2 & NREL & Yes & $\begin{array}{l}\text { Interaction between PV simulator and inverter can } \\
\text { cause fluctuations in inverter output power or can } \\
\text { cause inverter to fail to reach full power. This problem } \\
\text { occurs with a variety of PV inverters and grid } \\
\text { simulators, including string inverters and central } \\
\text { inverters. }\end{array}$ & $\begin{array}{l}\text { Use DC voltage source rather than PV } \\
\text { simulator. Or, change gains of PV simulator } \\
\text { to eliminate interactions (can be difficult or } \\
\text { time-consuming). }\end{array}$ & $\begin{array}{l}\text { Should simulated PV be required for any } \\
\text { tests? If so, what accuracy and dynamic } \\
\text { performance is required? }\end{array}$ & $\begin{array}{l}\text { P1547.1, UL } \\
1741 \text { STP }\end{array}$ \\
\hline 3 & NREL & Yes & $\begin{array}{l}\text { Interaction between DC supply and inverter can cause } \\
\text { fluctuations in inverter output power. Certain MPPT } \\
\text { methods may result in unexpected behavior when fed } \\
\text { by a power-limited voltage source (or a current- } \\
\text { limited voltage source). }\end{array}$ & $\begin{array}{l}\text { Use PV simulator instead of DC voltage } \\
\text { source (but note that PV simulator may } \\
\text { also cause undesired behavior). } \\
\text { Alternatively, put inverter in constant } \\
\text { power mode instead of MPPT mode (if } \\
\text { allowed). }\end{array}$ & $\begin{array}{l}\text { Can PV inverters be run in constant } \\
\text { power mode for some or all tests, or do } \\
\text { they have to be in MPPT mode? }\end{array}$ & $\begin{array}{l}\text { P1547.1, UL } \\
1741 \text { STP }\end{array}$ \\
\hline 4 & NREL & Yes & $\begin{array}{l}\text { Some inverters, including one of the inverters NREL } \\
\text { tested, are designed to be used with DC-DC converters } \\
\text { connected between the PV modules and the inverter. } \\
\text { It is often assumed that the DC-DC converters will not } \\
\text { affect the results of interconnection tests such as } \\
\text { those in UL } 1741 \text { and IEEE Std } 1547.1 \text {. However, this is } \\
\text { not always true. For example, during volt-VAR tests } \\
\text { the AC voltage at the inverter terminals goes to a high } \\
\text { level, and an inverter using DC optimizers may be } \\
\text { designed to regulate its DC bus to a higher level in } \\
\text { response. However, if the DC optimizers are not } \\
\text { present, the inverter may behave in unexpected ways } \\
\text { that do not accurately represent its field behavior. }\end{array}$ & $\begin{array}{l}\text { Some or all tests may need to be required } \\
\text { to be performed on systems as typically } \\
\text { installed in the field (i.e. including DC } \\
\text { optimizers or other components that may } \\
\text { affect test results) }\end{array}$ & & $\begin{array}{l}\text { P1547.1, UL } \\
1741 \text { STP }\end{array}$ \\
\hline
\end{tabular}




\begin{tabular}{|c|c|c|c|c|c|c|}
\hline $\begin{array}{l}\text { Finding } \\
\text { number }\end{array}$ & Lab & $\begin{array}{l}\text { ACCEL- } \\
\text { funded? }\end{array}$ & Lesson & Possible solution & Question(s) & Feedback to \\
\hline 5 & NREL & Yes & $\begin{array}{l}\text { While most inverters may be installed either as single } \\
\text { units or as systems of more than one unit, } \\
\text { microinverters are almost never installed as single } \\
\text { units. However, interconnection conformance testing } \\
\text { typically is performed on a single unit, even with } \\
\text { microinverters, when done at NRTLs. In contrast, NREL } \\
\text { typically tests systems of a dozen or more } \\
\text { microinverters and finds that this introduces some } \\
\text { noticeable differences in test results. For example, } \\
\text { with volt-VAR testing, each inverter sees a slightly } \\
\text { different voltage due to both measurement error and } \\
\text { small voltage drops in the lines connecting the } \\
\text { microinverters, so each microinverter tends to } \\
\text { operate at a different VAR level at any given time in } \\
\text { the test. }\end{array}$ & $\begin{array}{l}\text { NREL brought up this concern at the June } \\
\text { IEEE Std } 1547.1 \text { working group meeting. At } \\
\text { least one microinverter manufacturer } \\
\text { acknowledged that it may be better to test } \\
\text { systems of microinverters rather than } \\
\text { single units. However, this concern needs } \\
\text { to be balanced with the desire not to } \\
\text { impose requirements on one specific type } \\
\text { of DER that are not imposed on others. }\end{array}$ & & $\begin{array}{l}\text { P1547.1, UL } \\
1741 \text { STP }\end{array}$ \\
\hline 6 & NREL & Yes & $\begin{array}{l}\text { Voltage range of common grid simulators may not } \\
\text { reach } 120 \% \text { of } 277 / 480 \text { VAC, or power may be limited } \\
\text { when in higher voltage modes. Using a transformer to } \\
\text { step up the voltage adds significant impedance, which } \\
\text { makes tests requiring accurate control of voltage } \\
\text { more difficult, especially when inverter output power } \\
\text { varies during the test. }\end{array}$ & $\begin{array}{l}\text { Account for possible reduction of voltage } \\
\text { control accuracy in test design. Make test } \\
\text { labs aware of issue. }\end{array}$ & & $\begin{array}{l}\text { P1547.1, UL } \\
1741 \text { STP }\end{array}$ \\
\hline 7 & NREL & Yes & $\begin{array}{l}\text { P1547 frequency-watt test does define a small-signal } \\
\text { time response but does not define a large-signal time } \\
\text { response. }\end{array}$ & $\begin{array}{l}\text { Modify P1547. This was attempted and } \\
\text { faced significant opposition. Instead, the } \\
1547.1 \text { test will need to be designed to } \\
\text { deal with non-deterministic large signal } \\
\text { responses }\end{array}$ & & P1547, REG \\
\hline 8 & NREL & Yes & $\begin{array}{l}\text { UL } 1741 \text { and IEEE Std } 1547 \text { do not appear to make } \\
\text { explicit how reactive power should be measured. For } \\
\text { example, should only the fundamental frequency } \\
\text { reactive power be measured? Should any averaging be } \\
\text { used? Most test equipment (power analyzers) will } \\
\text { average over a few line cycles when calculating } \\
\text { reactive power. Is this acceptable? If so, are there } \\
\text { limits on averaging windows? For three-phase devices, } \\
\text { should the phases be considered separately or } \\
\text { together? }\end{array}$ & $\begin{array}{l}\text { UL } 1741 \text { and IEEE Std } 1547 \text { should make } \\
\text { explicit how reactive power should be } \\
\text { measured. }\end{array}$ & & REG \\
\hline
\end{tabular}




\begin{tabular}{|c|c|c|c|c|c|c|}
\hline $\begin{array}{l}\text { Finding } \\
\text { number }\end{array}$ & Lab & $\begin{array}{l}\text { ACCEL- } \\
\text { funded? }\end{array}$ & Lesson & Possible solution & Question(s) & Feedback to \\
\hline 9 & NREL & Yes & $\begin{array}{l}\text { NREL's volt-VAR testing to Hawaiian Electric's Rule } \\
14 \mathrm{H} \text { was made more challenging (both for NREL and } \\
\text { for the inverter manufacturers involved) by the fact } \\
\text { that Rule } 14 \mathrm{H} \text { requirements for volt-VAR control are } \\
\text { not very specific. For example, Rule } 14 \mathrm{H} \text { calls for volt- } \\
\text { VAR control down to } 0.85 \text { power factor, but it is not } \\
\text { clear whether this means the inverter should never } \\
\text { operate below } 0.85 \text { power factor, or that it must be } \\
\text { capable of providing reactive power that would give a } \\
0.85 \text { power factor when operating at full rated real } \\
\text { power. Test engineers had to make many assumptions } \\
\text { related to HECO's requirements. Similarly, inverter } \\
\text { manufacturers have difficulty designing to vague } \\
\text { requirements, and the resulting products may not } \\
\text { perform as the utility desires. }\end{array}$ & $\begin{array}{l}\text { IEEE Std } 1547 \text { will become the source } \\
\text { requirements document for IEEE Std } \\
1547.1 \text {, so good design of DER } \\
\text { requirements in IEEE Std } 1547 \text { will help } \\
\text { solve this issue. However, during the } \\
\text { interim period when UL } 1741 \text { is serving as a } \\
\text { test standard, more clarity in utility source } \\
\text { requirements documents is needed. }\end{array}$ & & P1547 \\
\hline 10 & NREL & Yes & $\begin{array}{l}\text { Very steep volt-VAR curves may not be stable as the } \\
\text { reactive power may interact dynamically with the } \\
\text { small impedances in the test setup to produce } \\
\text { oscillations in voltage and reactive power. }\end{array}$ & $\begin{array}{l}\text { Do not require testing of very steep volt- } \\
\text { VAR curves that would not be used in the } \\
\text { field. }\end{array}$ & $\begin{array}{l}\text { What is the reasonable range of volt- } \\
\text { VAR curves? }\end{array}$ & $\begin{array}{l}\text { REG, UL } 1741 \\
\text { STP }\end{array}$ \\
\hline 11 & NREL & Yes & $\begin{array}{l}\text { Some manufacturers support testing with a deadband } \\
\text { region so wide that for the "least aggressive" curve, } \\
\text { the sloping curve portions fall mostly or entirely } \\
\text { outside of the normal operating voltage range } \\
\text { (meaning the volt-VAR curve would result in non-zero } \\
\text { reactive power only during ride-through events, which } \\
\text { is not the intent of volt-VAR control). Again, such a } \\
\text { curve would likely not be used in the field and would } \\
\text { be difficult or impossible to test in the lab due to finite } \\
\text { voltage trip settings. }\end{array}$ & $\begin{array}{l}\text { The P1547.1 WG should consider the range } \\
\text { of allowable volt-VAR curves from P1547 } \\
\text { and if needed consider imposing } \\
\text { constraints on the selection of curves for } \\
\text { testing. This lesson learned applies to all } \\
\text { P1547.1 tests where a range of adjustable } \\
\text { curves are tested (volt-VAR, volt-watt, } \\
\text { frequency-watt, and others). }\end{array}$ & & $\begin{array}{l}\text { REG, UL } 1741 \\
\text { STP }\end{array}$ \\
\hline 11 & NREL & Yes & $\begin{array}{l}\text { For related regulation functions that can be active } \\
\text { simultaneously, is it required to test the simultaneous } \\
\text { operation? For example, P1547 requires any reactive } \\
\text { power mode to be capable of operating } \\
\text { simultaneously with volt-watt mode. }\end{array}$ & $\begin{array}{l}\text { REG subgroup should discuss when testing } \\
\text { of simultaneous functions should be } \\
\text { required. }\end{array}$ & & REG \\
\hline 12 & NREL & No & $\begin{array}{l}\text { Frequency-watt behavior can be unpredictable when } \\
\text { frequency is held near knee of } \mathrm{f}-\mathrm{W} \text { curve. This is } \\
\text { unlikely to be a problem in the field but can cause } \\
\text { problems in testing. }\end{array}$ & $\begin{array}{l}\text { Avoid knee of } \mathrm{f}-\mathrm{W} \text { curve in testing? Or, } \\
\text { require inverters be modified to mitigate } \\
\text { this behavior? }\end{array}$ & & REG, IMs \\
\hline
\end{tabular}




\begin{tabular}{|c|c|c|c|c|c|c|}
\hline $\begin{array}{l}\text { Finding } \\
\text { number }\end{array}$ & Lab & $\begin{array}{l}\text { ACCEL- } \\
\text { funded? }\end{array}$ & Lesson & Possible solution & Question(s) & Feedback to \\
\hline 13 & NREL & No & $\begin{array}{l}\text { Frequency-watt response time can vary depending on } \\
\text { whether frequency is rising or falling. }\end{array}$ & $\begin{array}{l}\text { Modify test to accommodate? Or require } \\
\text { IMs to implement same response time? }\end{array}$ & $\begin{array}{l}\text { Is it reasonable to require response time } \\
\text { be uniform and tightly controlled? } 1547 \\
\text { provides exceptions for prime mover } \\
\text { limitations, but how do we know if a } \\
\text { response time that does not match the } \\
\text { expected value is a result of prime } \\
\text { mover limitations or poor control } \\
\text { design? }\end{array}$ & REG \\
\hline 14 & NREL & Yes & $\begin{array}{l}\text { Many inverter manufacturers do not yet support the } \\
\text { wide range of new functions required by P1547. }\end{array}$ & Stakeholder education will be necessary. & & IMs \\
\hline 15 & NREL & Yes & $\begin{array}{l}\text { The new grid support functions require IMs to define a } \\
\text { large number of new values that are needed for test } \\
\text { setup. Many IMs currently do not put these value in } \\
\text { spec sheets or manuals. }\end{array}$ & $\begin{array}{l}\text { NTRLs work with IMs to obtain test values. } \\
\text { P1547.1 should contain a consolidated list } \\
\text { of all values needed, with definitions and } \\
\text { units. }\end{array}$ & & P1547.1 \\
\hline 16 & NREL & Yes & $\begin{array}{l}\text { The grid simulator tripped intermittently for some } \\
\text { LVRT tests. Tripping has been observed only in the } \\
\text { following conditions: } \\
\text { - LVRT tests for the low voltage region } 3(\mathrm{~V}<50 \%) \\
\text { - When the voltage goes from low to high }\end{array}$ & $\begin{array}{l}\text { Need to work with grid simulator } \\
\text { manufacturer and IM to find out the root } \\
\text { cause of this issue and ways to avoid grid } \\
\text { sim tripping. }\end{array}$ & $\begin{array}{l}\text { Is residual transformer flux causing this } \\
\text { issue? }\end{array}$ & $\begin{array}{l}\text { Grid } \\
\text { simulator } \\
\text { manufacturer }\end{array}$ \\
\hline 17 & NREL & Yes & $\begin{array}{l}\text { When a transformer is part of the inverter, the } \\
\text { transformer non-idealities introduce unbalance in } \\
\text { voltage though the applied the voltage from the grid } \\
\text { simulator is balanced. Considerable error has been } \\
\text { observed between lab test result and expected result } \\
\text { due to the unbalanced voltage introduced by the } \\
\text { transformer. }\end{array}$ & $\begin{array}{l}\text { UL } 1741 \text { and IEEE Std } 1547 \text { should make } \\
\text { explicit how unbalance voltage introduced } \\
\text { by transformer should be treated }\end{array}$ & & $\begin{array}{l}\text { REG, UL } 1741 \\
\text { STP }\end{array}$ \\
\hline 18 & NREL & Yes & $\begin{array}{l}\text { When in volt-VAR mode, the inverter changes its } \\
\text { reactive power based on the voltage at the inverter } \\
\text { side of the transformer if a transformer is part of the } \\
\text { inverter. However, the voltage change across the } \\
\text { transformer is different for the case when the reactive } \\
\text { power output changes with respect to voltage than } \\
\text { the case when the inverter reaches its maximum or } \\
\text { minimum reactive power limit. }\end{array}$ & Make test labs aware of issue. & & REG \\
\hline
\end{tabular}




\begin{tabular}{|c|c|c|c|c|c|c|}
\hline $\begin{array}{l}\text { Finding } \\
\text { number }\end{array}$ & Lab & $\begin{array}{l}\text { ACCEL- } \\
\text { funded? }\end{array}$ & Lesson & Possible solution & Question(s) & Feedback to \\
\hline 19 & NREL & Yes & $\begin{array}{l}\text { For a } \Delta-Y \text { transformer, there will be always some } \\
\text { induced voltage in one side of the transformer if zero } \\
\text { voltage is applied in one of the phases of the other } \\
\text { side. This will create a problem for low voltage ride } \\
\text { through test which requires zero voltage applied to an } \\
\text { individual phase for a multiphase unit. }\end{array}$ & $\begin{array}{l}\text { UL } 1741 \text { and IEEE Std } 1547 \text { should make } \\
\text { explicit how to circumvent this problem. }\end{array}$ & & V\&F \\
\hline 20 & SNL & Yes & $\begin{array}{l}\text { UL 1741SA has two modes for specified Power Factor: } \\
\text { 1) fixed power factor(FPF)-where the desired PF is } \\
\text { commanded, 2) power factor with active power } \\
\text { priority (PFAP)-may be used in special cases and } \\
\text { agreements with EPS operator. With PFAP- target PF } \\
\text { may not be met. }\end{array}$ & $\begin{array}{l}\text { UL } 1741 \text { should agree with IEEE Std } 1547 \\
\text { and not have PFAP since the commanded } \\
\text { PF may not be met because of active } \\
\text { power requirements }\end{array}$ & $\begin{array}{l}\text { Do any inverters have this PFAP } \\
\text { capability? }\end{array}$ & $\begin{array}{l}\text { REG, UL } 1741 \\
\text { STP }\end{array}$ \\
\hline 21 & SNL & YES & $\begin{array}{l}\text { UL } 1741 \text { SA tends to use SPF (specified power factor) } \\
\text { and FPF (fixed power factor) interchangeably. The UI } \\
\text { test procedure calls for SPF but doesn't mention mode } \\
\text { of SPF. }\end{array}$ & Equate SPF to FPF & & $\begin{array}{l}\text { REG, UL } 1741 \\
\text { STP }\end{array}$ \\
\hline 22 & SNL & Yes & $\begin{array}{l}\text { UL } 1741 \text { SA only has one UI circuit and since systems } \\
\text { can be wye connected and some can be delta } \\
\text { connected, there should be two circuit options } \\
\text { detailing the load configuration }\end{array}$ & $\begin{array}{l}\text { Include two circuits for the RLC to show } \\
\text { differentiate between wye and delta } \\
\text { connected inverters and loads }\end{array}$ & & $\begin{array}{l}\text { UI, UL } 1741 \\
\text { STP }\end{array}$ \\
\hline 23 & SNL & Yes & $\begin{array}{l}\text { UI1741SA UI section calls for an SRD specifying volt- } \\
\text { VAR priority. If SRD does not specify, VAR priority } \\
\text { should be default choice. }\end{array}$ & Specify what the default priority should be. & & $\begin{array}{l}\text { UI, UL } 1741 \\
\text { STP }\end{array}$ \\
\hline 24 & SNL & Yes & $\begin{array}{l}\text { The load bank used for UI testing at SNL only has a } \\
\text { delta configuration and some of the devices tested are } \\
\text { wye connected devices }\end{array}$ & $\begin{array}{l}\text { Either introduce a high impedance } \\
\text { connection to neutral or procure a wye } \\
\text { connected RLC load bank }\end{array}$ & & $\mathrm{UI}$ \\
\hline 25 & SNL & Yes & $\begin{array}{l}\text { LVRT testing for LV3 has shown some inverters have } \\
\text { peculiar responses during recovery from momentary } \\
\text { cessation }\end{array}$ & $\begin{array}{l}\text { Since the response is well within the } 2 \\
\text { second requirement to get back to } 80 \% \text { of } \\
\text { pre-event values, perhaps addressing the } \\
\text { oscillation type recovery is beneficial }\end{array}$ & & IMs \\
\hline 26 & SNL & Yes & $\begin{array}{l}\text { UL1741 requires for the input source rating to be } \\
125 \% \text { of EUT's rated current but the EUT only uses the } \\
\text { current at max power point. }\end{array}$ & $\begin{array}{l}\text { While the } 125 \% \text { may be sufficient, I believe } \\
\text { requiring } 140-150 \% \text { would be best. }\end{array}$ & $\begin{array}{l}\text { What should be the P1547.1 } \\
\text { requirements on AC supplies used for } \\
\text { type testing? }\end{array}$ & $\begin{array}{l}\text { GR, REG, UL } \\
1741 \text { STP }\end{array}$ \\
\hline 27 & SNL & Yes & $\begin{array}{l}\text { PV simulator and inverter interactions are at times } \\
\text { unfavorable with the following issues: power } \\
\text { fluctuations when excessive power is available on the } \\
\text { DC side. This happens during reactive power } \\
\text { generation during SPF, volt-VAR, volt-watt, and power } \\
\text { curtailment. }\end{array}$ & $\begin{array}{l}\text { Adjust PV sim MPPT parameters. This will } \\
\text { require manufacturers guidance and we } \\
\text { haven't received feedback from our } \\
\text { request }\end{array}$ & $\begin{array}{l}\text { What should be the P1547.1 } \\
\text { requirements, if any, on prime movers } \\
\text { powering DERs (e.g. PV array vs PV } \\
\text { simulator vs DC supply)? }\end{array}$ & $\begin{array}{l}\text { GR, PV sim } \\
\text { manufacturer }\end{array}$ \\
\hline
\end{tabular}

This report is available at no cost from the National Renewable Energy Laboratory (NREL) at www.nrel.gov/publications. 


\begin{tabular}{|c|c|c|c|c|c|c|}
\hline $\begin{array}{l}\text { Finding } \\
\text { number }\end{array}$ & Lab & $\begin{array}{l}\text { ACCEL- } \\
\text { funded? }\end{array}$ & Lesson & Possible solution & Question(s) & Feedback to \\
\hline 28 & NREL & Yes & $\begin{array}{l}\text { Fault responses of various inverters are non-uniform } \\
\text { and may not be well-characterized by a small number } \\
\text { of tests. The quantity of type tests needed to fully } \\
\text { characterize inverter fault responses is large for some } \\
\text { inverters. }\end{array}$ & $\begin{array}{l}\text { M\&S subgroup will need to come to a } \\
\text { compromise between utility desire to know } \\
\text { more about inverter fault responses and } \\
\text { industry desire for a not-unreasonable } \\
\text { testing burden. }\end{array}$ & & $M \& S$ \\
\hline 29 & NREL & Yes & $\begin{array}{l}\text { Many inverter fault responses today do not meet the } \\
1547-2018 \text { LVRT requirements to maintain } 80 \% \text { of pre- } \\
\text { fault current magnitude under certain conditions. }\end{array}$ & $\begin{array}{l}\text { May need to wait till inverters are updated } \\
\text { per } 1547-2018\end{array}$ & $\begin{array}{l}\text { How will inverter fault responses change } \\
\text { when inverters are updated per 1547- } \\
2018 \text { ? When should we expect to see } \\
\text { those changes in products? }\end{array}$ & $M \& S$ \\
\hline 30 & $\begin{array}{l}\text { SNL, } \\
\text { NREL }\end{array}$ & Yes & $\begin{array}{l}\text { Tests confirm the new UI subgroup method for } \\
\text { reducing the number of islanding tests while } \\
\text { improving test reliability works well, at least in certain } \\
\text { cases. In other cases, it is difficult or impossible to } \\
\text { validate the test setup by intentionally creating a } \\
\text { sustained island, so some DERs will likely need to use } \\
\text { a more conventional procedure with additional tests. }\end{array}$ & $\begin{array}{l}\text { Move forward with new UI test design as } \\
\text { an optional method to improve testing, } \\
\text { while still allowing the option to test using } \\
\text { a more conventional procedure where } \\
\text { appropriate. }\end{array}$ & $\begin{array}{l}\text { How long must an island persist for the } \\
\text { DER-load combination to be considered } \\
\text { well-balanced for UI test purposes? } 2 \\
\text { seconds? Longer? }\end{array}$ & $\mathrm{UI}$ \\
\hline 31 & SNL & Yes & $\begin{array}{l}\text { Simulating a fault condition using a grid simulator (AC } \\
\text { supply) without creating an actual fault appears to be } \\
\text { a reasonable method of characterizing inverter fault } \\
\text { current, at least for the quasi-steady-state fault } \\
\text { response that is of most interest to utilities. }\end{array}$ & $\begin{array}{l}\text { Allow fault testing using a grid simulator, } \\
\text { without creating a physical fault, as an } \\
\text { option for type testing. }\end{array}$ & $\begin{array}{l}\text { Further testing may be needed to fully } \\
\text { validate this method, especially for the } \\
\text { transient response. (See lesson } 35 . \text { ) }\end{array}$ & $M \& S$ \\
\hline 32 & NREL & Yes & $\begin{array}{l}\text { The frequency-watt test procedure developed so far } \\
\text { appears largely adequate. Minor questions and } \\
\text { comments were made and sent to the REG subgroup } \\
\text { leader. }\end{array}$ & & $\begin{array}{l}\text { How should we deal with DER } \\
\text { performance accuracy? The test criteria } \\
\text { will impose a de facto requirement on } \\
\text { performance accuracy that is not } \\
\text { specified in } 1547-2018 \text {, so this needs to } \\
\text { be thought through }\end{array}$ & REG, GR \\
\hline 33 & NREL & Yes & $\begin{array}{l}\text { In the test for } \mathrm{f}-\mathrm{W} \text { time response, the time response } \\
\text { of some inverters is a function of the step size. This } \\
\text { needs to be reconciled with inverter industry } \\
\text { statements that the time response for large steps can } \\
\text { be just as fast as the time response for smaller steps. }\end{array}$ & $\begin{array}{l}\text { Allow testing of faster responses for larger } \\
\text { steps to validate behavior if available, but } \\
\text { do not require this for all DERs }\end{array}$ & & REG \\
\hline 34 & NREL & Yes & $\begin{array}{l}\text { Misbehavior of test equipment can throw off test } \\
\text { results, potentially making it appear that a DER passed } \\
\text { a test when the result was actually inconclusive. }\end{array}$ & Test engineers need to be vigilant. & & GR \\
\hline
\end{tabular}




\begin{tabular}{|c|c|c|c|c|c|c|}
\hline $\begin{array}{l}\text { Finding } \\
\text { number }\end{array}$ & Lab & $\begin{array}{l}\text { ACCEL- } \\
\text { funded? }\end{array}$ & Lesson & Possible solution & Question(s) & Feedback to \\
\hline 35 & NREL & Yes & $\begin{array}{l}\text { Inverter response to a true three-phase fault is similar } \\
\text { to inverter response to emulating a three-phase fault } \\
\text { using a grid simulator by programming a sudden } \\
\text { change to zero volts. This confirms the test proposed } \\
\text { by the } M \& S \text { subgroup is valid, at least for } 3 \text {-phase } \\
\text { fault current response. }\end{array}$ & & & $M \& S$ \\
\hline 36 & NREL & Yes & $\begin{array}{l}\text { Response to unbalanced faults appears to depend on } \\
\text { test configuration details, such as presence and type } \\
\text { of transformers, presence and configuration of load, } \\
\text { and presence or absence of neutral connection. }\end{array}$ & $\begin{array}{l}\text { Additional testing and analysis are needed } \\
\text { to determine best test procedure for } \\
\text { unbalanced fault response. }\end{array}$ & $\begin{array}{l}\text { What questions are we trying answer } \\
\text { with the fault current characterization } \\
\text { tests, and what is out of scope for } \\
1547.1 \text { ? What is the best test } \\
\text { configuration to answer those } \\
\text { questions? }\end{array}$ & $M \& S$ \\
\hline 37 & SNL & Yes & $\begin{array}{l}\text { For the must-trip setting on all device categories and } \\
\text { the range of adjustability, the range needs to be } \\
\text { sufficient to address profiles under development }\end{array}$ & $\begin{array}{l}\text { Trip range of adjustability needs to be wide } \\
\text { enough to account for profiles with largest } \\
\text { variance }\end{array}$ & $\begin{array}{l}\text { Should trip range of adjustability also } \\
\text { consider micro-grid application? }\end{array}$ & IMs \\
\hline 39 & SNL & Yes & $\begin{array}{l}\text { Possible false results of function under evaluation can } \\
\text { be observed if similar functions are left on. }\end{array}$ & $\begin{array}{l}\text { Avoid interference and false results from } \\
\text { similar functions by turning off all functions } \\
\text { except function being evaluated. }\end{array}$ & & REG \\
\hline 40 & SNL & Yes & $\begin{array}{l}\text { Range of adjustability for functions can create } \\
\text { unwanted/desired operations. Example: Volt-Var } \\
\text { functions can have a vertical (step change) in reactive } \\
\text { power if range of adjustability is adhered to. }\end{array}$ & $\begin{array}{l}\text { Limit the range of adjustability to } \\
\text { reasonable values }\end{array}$ & $\begin{array}{l}\text { What/who governs the } \\
\text { reasonable/practical ranges for } \\
\text { functions that may cause undesired } \\
\text { operation? }\end{array}$ & REG/Ims \\
\hline 41 & SNL & Yes & $\begin{array}{l}\text { Short Circuit data requirements must be specified } \\
\text { beyond oscillatory. The short circuit current } \\
\text { contribution from DER can be transient and RMS type }\end{array}$ & $\begin{array}{l}\text { From the oscillograph data determine both } \\
\text { transient and RMS values }\end{array}$ & $\begin{array}{l}\text { transient values (typically single-digit } \\
\text { milli-sec) in inverter based DER can be 2- } \\
3 \text { PU but will not trip protection devices }\end{array}$ & $M \& S$ \\
\hline
\end{tabular}




\begin{tabular}{|c|c|c|c|c|c|c|}
\hline $\begin{array}{l}\text { Finding } \\
\text { number }\end{array}$ & Lab & $\begin{array}{l}\text { ACCEL- } \\
\text { funded? }\end{array}$ & Lesson & Possible solution & Question(s) & Feedback to \\
\hline 43 & NREL & Yes & $\begin{array}{l}\text { Inverter fault responses vary widely between } \\
\text { inverters. There can also be wide variation in any } \\
\text { single inverter's response depending on residual } \\
\text { voltage. This makes it challenging to define a fault test } \\
\text { procedure that thoroughly characterizes an inverter's } \\
\text { behavior in a small number of tests. }\end{array}$ & $\begin{array}{l}\text { Increase number of tests? Decide what } \\
\text { conditions are most important, and only } \\
\text { test those? }\end{array}$ & $\begin{array}{l}\text { How will inverter fault responses change } \\
\text { when inverters are updated per 1547- } \\
2018 \text { ? When should we expect to see } \\
\text { those changes in products? }\end{array}$ & $M \& S$ \\
\hline
\end{tabular}

